Review Article

\title{
Heteroreceptors Modulating CGRP Release at Neurovascular Junction: Potential Therapeutic Implications on Some Vascular-Related Diseases
}

\author{
Abimael González-Hernández, ${ }^{1}$ Bruno A. Marichal-Cancino, ${ }^{2}$ \\ Jair Lozano-Cuenca, ${ }^{3}$ Jorge S. López-Canales, ${ }^{3}$ Enriqueta Muñoz-Islas, ${ }^{4}$ \\ Martha B. Ramírez-Rosas, ${ }^{4}$ and Carlos M. Villalón ${ }^{2}$ \\ ${ }^{1}$ Departamento de Neurobiología del Desarrollo y Neurofisiología, Instituto de Neurobiología, \\ Universidad Nacional Autónoma de México, 76230 Santiago de Querétaro, QRO, Mexico \\ ${ }^{2}$ Departamento de Farmacobiología, Centro de Investigación y de Estudios Avanzados del IPN-Sede Sur, 14330 Mexico City, Mexico \\ ${ }^{3}$ Departamento de Fisiología y Desarrollo Celular, Instituto Nacional de Perinatología, Secretaría de Salud, 11000 Mexico City, Mexico \\ ${ }^{4}$ Unidad Académica Multidisciplinaria Reynosa-Aztlán, Universidad Autónoma de Tamaulipas, 88740 Reynosa, TAMPS, Mexico
}

Correspondence should be addressed to Abimael González-Hernández; abimaelgh@gmail.com

Received 31 May 2016; Revised 12 November 2016; Accepted 27 November 2016

Academic Editor: John D. Wade

Copyright (C) 2016 Abimael González-Hernández et al. This is an open access article distributed under the Creative Commons Attribution License, which permits unrestricted use, distribution, and reproduction in any medium, provided the original work is properly cited.

\begin{abstract}
Calcitonin gene-related peptide (CGRP) is a 37-amino-acid neuropeptide belonging to the calcitonin gene peptide superfamily. CGRP is a potent vasodilator with potential therapeutic usefulness for treating vascular-related disease. This peptide is primarily located on $\mathrm{C}$ - and $\mathrm{A} \delta$-fibers, which have extensive perivascular presence and a dual sensory-efferent function. Although CGRP has two major isoforms ( $\alpha$-CGRP and $\beta$-CGRP), the $\alpha$-CGRP is the isoform related to vascular actions. Release of CGRP from afferent perivascular nerve terminals has been shown to result in vasodilatation, an effect mediated by at least one receptor (the CGRP receptor). This receptor is an atypical G-protein coupled receptor (GPCR) composed of three functional proteins: (i) the calcitonin receptor-like receptor (CRLR; a seven-transmembrane protein), (ii) the activity-modifying protein type 1 (RAMP1), and (iii) a receptor component protein (RCP). Although under physiological conditions, CGRP seems not to play an important role in vascular tone regulation, this peptide has been strongly related as a key player in migraine and other vascular-related disorders (e.g., hypertension and preeclampsia). The present review aims at providing an overview on the role of sensory fibers and CGRP release on the modulation of vascular tone.
\end{abstract}

\section{Introduction}

Blood pressure is mainly regulated by vascular peripheral resistance and cardiac output. From a physiological perspective, vascular peripheral resistance depends (at least 50\%) on the vascular tone which, in turn, is maintained by the interaction between several systems and mechanisms (autonomic, endocrine, and local). In normal conditions, vascular tone is mainly modulated by the autonomic nervous system (ANS), with a predominant function of the sympathetic division. Certainly, the parasympathetic vagus nerve has strong influence on the heart rate during baroreflex. Blood pressure is regulated at different levels; for example: at the periphery, several receptors can detect changes in the vascular resistance (baroreceptors) or changes in the chemical concentrations (chemoreceptors). These sensory extensions of the peripheral nervous system send afferent impulses to the brainstem where the neuronal activity of the efferent sympathetic nerves is controlled in order to adjust cardiac output and vascular resistance. At the central level, the activity of the ANS is regulated by the integration of neuronal reflexes in the brainstem and hormonal secretion from the pituitary gland. The actions of the ANS are classically mediated by the release of noradrenaline (NA) or acetylcholine (ACh) [1]. In the case 
TABLE 1: NANC neuromediators. Some NANC neuromediators identified on autonomic and sensory fibers. It is important to point out that several of these neuromediators are coreleased with other neurotransmitters. ADM, adrenomedullin; ATP, adenosine triphosphate; cAMP, cyclic adenosine monophosphate; cGMP, cyclic guanosine monophosphate; CGRP, calcitonin gene-related peptide; IP ${ }_{3}$, inositol triphosphate; $\mathrm{K}^{+}{ }_{\text {ATP }}$, ATP-sensitive potassium channel; $\mathrm{K}^{+} \mathrm{Ca}^{2+}$, calcium-activated potassium channel; NO, nitric oxide; NPY, neuropeptide Y; PAF, primary afferent fibers; PKC, protein kinase C; SP, substance P; VIP, vasoactive intestinal peptide.

\begin{tabular}{|c|c|c|c|c|}
\hline Neuromediator & Localization & Receptor & $\begin{array}{c}\text { Second } \\
\text { messengers }\end{array}$ & Functional response \\
\hline CGRP, ADM, amylin & Sensory neurons (PAF) & CGRP & $\begin{array}{l}\text { cAMP } \\
\mathrm{K}_{\text {ATP }}^{+} \\
\end{array}$ & $\begin{array}{c}\text { Vasodilatation } \\
\text { tachycardia }\end{array}$ \\
\hline ATP & Sympathetic postganglionic neurons & $\begin{array}{l}\mathrm{P}_{2 x} \\
\mathrm{P}_{2 y}\end{array}$ & $\begin{array}{c}\mathrm{Ca}^{2+} \\
\mathrm{IP}_{3}, \mathrm{Ca}^{2+} \\
\mathrm{PKC}, \mathrm{NO}\end{array}$ & $\begin{array}{l}\text { Smooth muscle } \\
\text { contraction }\end{array}$ \\
\hline VIP & Parasympathetic neurons & VPAC $_{1}$ & $\begin{array}{c}\text { cAMP } \\
\mathrm{K}^{+}\end{array}$ & $\begin{array}{c}\text { Vasodilatation } \\
\text { bronchodilatation }\end{array}$ \\
\hline NPY & Sympathetic postganglionic neurons & $\begin{array}{l}\mathrm{Y}_{1} \\
\mathrm{Y}_{2}\end{array}$ & $\begin{array}{l}\mathrm{Ca}^{2+} \\
\mathrm{cAMP}\end{array}$ & Vasoconstriction \\
\hline SP & Enteric sensory neurons & $\mathrm{NK}_{1}$ & $\begin{array}{c}\mathrm{IP}_{3}, \mathrm{Ca}^{2+} \\
\mathrm{PKC}\end{array}$ & $\begin{array}{c}\text { Vascular extravasation, } \\
\text { depolarization of PAF, } \\
\text { vasodilatation }\end{array}$ \\
\hline $\mathrm{NO}$ & Parasympathetic neurons & - & $\begin{array}{c}\text { cGMP } \\
\text { PGs, } \mathrm{K}^{+} \mathrm{Ca}^{2+}\end{array}$ & Vasodilatation \\
\hline
\end{tabular}

Data from [11, 21].

of resistance blood vessels, NA is tonically released by the sympathetic fibers exerting a tonic vasoconstriction [2].

In the last 25 years, the role of afferent sensory nerves modulating the vascular tone has emerged. Indeed, sensory nerves may have a direct effect on regulating blood pressure rather than the simple afferent role which had been initially thought. In fact, the neuronal mechanisms associated with regulation of the vascular tone are mediated not only by the sympathetic nervous system, but also by the nonadrenergic noncholinergic (NANC) neurotransmission [3]. Certainly, this NANC neurotransmission is mediated by the autonomic and sensory (afferent) nervous system.

\section{A Short Overview of the Nonadrenergic Noncholinergic (NANC) Neurotransmission}

The role of NANC neurotransmission on the vascular tone regulation is derived from a number of studies showing that, apart from NA and ACh, several neuromediators released by the ANS participate in the regulation of smooth muscle contractility (for a historical perspective, see [4]). Initially, this NANC neurotransmission had been mainly related to purinergic [5] and nitrergic [6] transmission. Indeed, this NANC neurotransmission was primarily associated with the role of ATP as an inhibitor cotransmitter at the level of neuroeffector junction of the intestinal smooth muscle [7]. Later on, it was demonstrated that ATP could be coreleased not only from the autonomic sympathetic fibers, but also from the NANC fibers $[8,9]$. In the 80 s, several NANC mediators modulating neurotransmission were described [10]. Currently, this neurotransmission involves neuromediators released by the autonomic and sensory nerves (Table 1).
The role of NANC neurotransmission in the resistance vascular function has a predominant vasodilator component, an effect opposite to the contractile effect induced by sympathetic adrenergic stimulation. In this case, the most important vasodilator neuromediators are calcitonin generelated peptide (CGRP), substance $\mathrm{P}$ (SP), nitric oxide (NO), and adenosine triphosphate (ATP) (see [11]). All these neuromediators are expressed in sensory and autonomic fibers. One important finding about this type of neurotransmission is the fact that activation of sensory NANC fibers can modulate the activity of sympathetic neurons [12]. In this context, Kawasaki et al. [13] and Han et al. [14] suggested that the electrically induced release of CGRP from perivascular sensory fibers deriving from the dorsal root ganglia (DRG) is responsible for relaxation of the arterial mesenteric bed. Accordingly, the neural control of cardiovascular function is mainly associated not only with activation of autonomic postganglionic nerve fibers, but also with activation of primary afferent (peptidergic) sensory fibers (Figure 1) $[3,15,16]$.

\section{The Sensory CGRPergic Neurons and Vascular Tone}

Classically, the nerves deriving from dorsal root ganglia (DRG) have been classified as sensory nerves, the functions of which are mainly related to the detection, transduction, and transmission of peripheral stimuli. However, these sensory nerves also seem to exert an efferent function (i.e., respond intrinsically to specific stimuli). For example, stimulation of the peripheral ends of cut DRG results in a vasodilator response by an antidromic conduction [17]. Similar results are obtained with strong stimuli on the human skin [18], an 


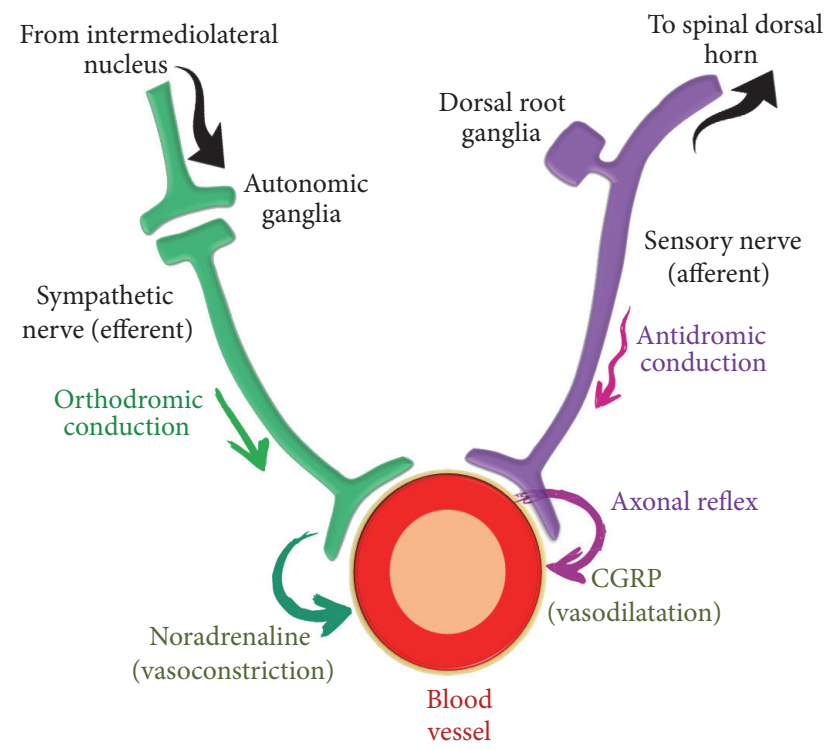

FIGURE 1: Vascular sympathetic and CGRPergic neurotransmission. The vascular tone is mainly regulated by the autonomic nervous system (ANS) innervation, but the sensory nerves play a pivotal role not only as sensors but also as effector. In the case of the ANS, the sympathetic branch exerts a tonic vasoconstriction by noradrenaline release whereas the sensory fibers release the calcitonin gene-related peptide and evokes vasodilatation. It is interesting to note that CGRP release from sensory nerves could be induced by (i) an axonal reflex and (ii) a dorsal root reflex inducing an antidromic conduction on the primary afferent fiber.

effect mediated by the so-called axon reflex. Based on velocity nerve conduction, fibers of DRG are classified into four types, namely: (i) A $\alpha$-fibers, (ii) $\mathrm{A} \beta$-fibers, (iii) $\mathrm{A} \delta$-fibers, and (iv) C-fibers $[19,20]$.

It is noteworthy that the main type of fibers involved in sensory NANC neurotransmission are the nociceptive fibers (i.e., $\mathrm{A} \delta$ - and C-fibers). These primary afferent fibers (PAF) are classically related to the transmission of the nociceptive information to the superficial (I-II) and deep (V-VI) layers of the spinal dorsal horn [33]. In this context, one important molecular marker in these sensory neurons is CGRP. This neuropeptide is mainly expressed in the small unmyelinated fibers (C-fibers), but also (in minor proportion) in the medium (A $\delta$-fibers) and large (A $\alpha$-fibers and $\mathrm{A} \beta$-fibers) myelinated fibers.

In the cardiovascular system, the activation of PAF has been associated with the changes in (i) vascular tone, (ii) autonomic neurotransmission at ganglionic level, and (iii) cardiac function [11], an effect probably mediated in all cases by CGRP release. Indeed, several blood vessels (including the coronary arteries) are highly innervated by peptidergic (CGRP and substance P) sensory fibers [34]. Moreover, some studies using knockout mice have suggested that CGRP plays a key role to maintain blood pressure [35]. At cardiac level, the 8-methyl-N-vanillil-6-noneamide or capsaicin (the pungent component of chili pepper) increases the chronotropic, inotropic responses [3] and induces coronary vasodilatation [36]. Furthermore, intracutaneously administered capsaicin increases the skin blood flow [37]. In both cases, this effect is due to release of CGRP from the sensory fibers by activation of transient receptor potential vanilloid receptors (TRPV1) on capsaicin-sensitive fibers (i.e., C-fibers) [38].

\section{Calcitonin Gene-Related Peptide}

4.1. CGRP Distribution. Since its discovery, CGRP has been involved with actions on blood vessels [39]. This neuropeptide is extensively distributed in the central nervous system (CNS) and peripheral nervous system (PNS) [39, 40]. In the CNS, CGRP is highly expressed in the spinal dorsal horn, cerebral cortex, gyrus dentatus, substantia nigra, and in minor proportion in the neocortex, globus pallidus, hippocampus, amygdala, thalamus, hypothalamus, and sympathetic ganglia [41]. At vascular level, the terminal CGRPergic sensory fibers are located in all layers of the vascular smooth muscle [39, 42, 43]. Indeed, the localization of CGRP in perivascular neurons is common to all vascular beds, at the adventitial-medial border, passing into the muscle layer, having a higher localization in arterial than venous tissues (in this case on human epicardial coronary arteries) [44]. Receptors for CGRP have been identified in both media and intima of resistance vessels and in endothelial cells [40, 42]. Due to a wide distribution of CGRP and its receptor in the vascular system, this peptide seems to be relevant as a potential drug target.

4.2. CGRP: Synthesis, Release, and Receptors. CGRP has two isoforms, namely, $\alpha$-CGRP and $\beta$-CGRP, both are present in humans and rodents. These isoforms are constituted by 37 amino acids [45]. The main difference in the primary structure of $\alpha$-CGRP and $\beta$-CGRP in humans lies in three amino acids (Figure 2 ) whereas in the rat only one amino acid is changed. One important issue about these isoforms is their distribution; $\alpha$-CGRP is mainly found in sensory neurons, whereas $\beta$-CGRP is found in the enteric nervous system and the pituitary gland [45-47]. Although the biological activity mediated by the CGRP receptor is similar for both isoforms, in the cardiovascular system the $\alpha$-CGRP is the isoform that plays a key role.

These neuropeptides are synthetized in the CNS and PNS and form part of the calcitonin peptides family, which comprises at least six members, namely: (i) calcitonin, (ii) amylin, (iii) $\alpha$-CGRP, (iv) $\beta$-CGRP, (v) adrenomedullin, and (vi) intermedin [46-48]. CGRP can be released from the $\mathrm{A} \delta$ - and C-fibers after activation of TRPV1 channels; if this stimulation is strong enough, an antidromic conduction may be induced, and probably also an axonal reflex, as previously suggested [49]. In this respect, Holzer and Maggi [50] proposed that CGRP is released tonically from sensory nerves. This hypothesis implied (i) that perivascular CGRPergic sensory neurons play an important role in the modulation of vascular tone and (ii) the existence of a CGRP receptor in the vasculature. These views were subsequently supported by other lines of evidence showing circulating plasma concentrations of CGRP (picogram/picomolar concentrations) in different species $[51,52]$. 


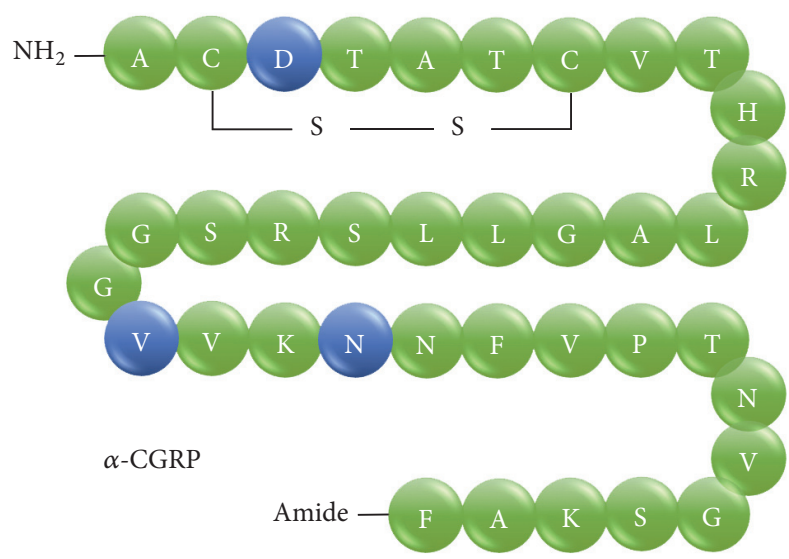

(a)

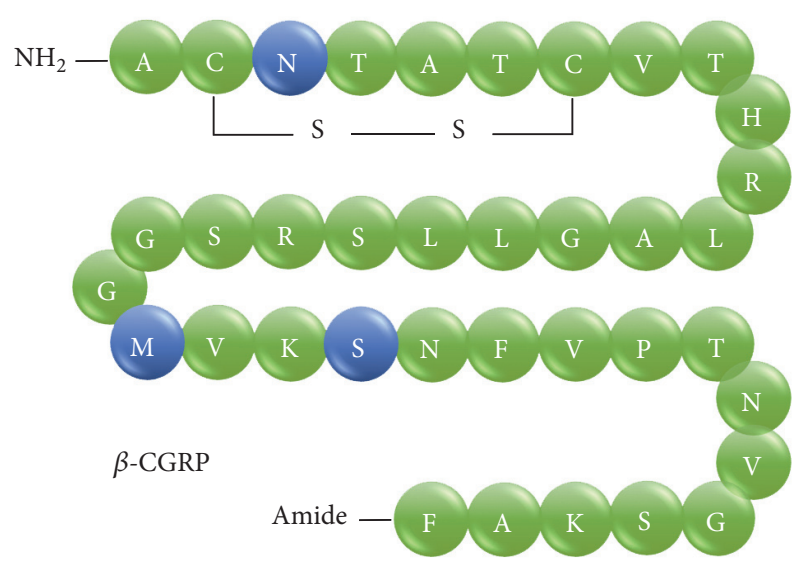

(b)

FIGURE 2: Protein primary structure of human CGRP. The calcitonin gene-related peptide (CGRP) is neuropeptide composed of 37 amino acids and could be expressed in two isoforms, $\alpha$-CGRP and $\beta$-CGRP (in humans and rodents). It is interesting to note that in the case of human isoforms, the difference in the polypeptide sequence is observed in three amino acids in the position 3, 22, and 25. One major difference is the fact that $\alpha$-CGRP is primary found in the sensory neurons whereas $\beta$-CGRP is mainly found in the enteric nervous system and the pituitary gland.

Early, two types of CGRP receptors were described, the $\mathrm{CGRP}_{1}$ and $\mathrm{CGRP}_{2}$ receptors [47]. More recently, the International Union of Basic and Clinical Pharmacology (IUPHAR) has recognized the existence of only one receptor [53]. Nevertheless, new evidence seems to suggest the presence of a second receptor, at least in coronary arteries [54]. In any case, the CGRP receptor(s) belongs to the metabotropic G-protein coupled receptor (GPCR) superfamily. This receptor is coupled to $G_{s}$ proteins (which activate adenylyl cyclase) and can interact with amylin and adrenomedullin (ADM) [55]. In addition, this receptor is considered an atypical GPCR, since apart from the calcitonin receptor-like receptor (CRLR; the seven-transmembrane protein) it requires the presence of an accessory protein named receptor activitymodifying protein 1 (RAMP1). This accessory protein gives the specificity to be activated by CGRP [55-57]. Finally, a third cytoplasmic or membrane protein required for signaling mechanisms has been identified, the RCP or receptor component protein [58]. In brief, to be functional, the CGRP receptor is composed by tree proteins forming a CRLRRAMP1-RCP complex (Figure 3).

\section{CGRP and Vascular Tone Modulation}

5.1. Overview. CGRP has several effects on the cardiovascular system (see Table 2) and is a potent microvascular vasodilator. Indeed, this neuropeptide is 100-1000 times more potent as vasodilator than adenosine, SP, or acetylcholine [59], and its effects can be specifically blocked by the peptide fragment $\mathrm{CGRP}_{8-37}$ [60]. Furthermore, CGRP also induces significant and selective hemodynamic effects such as increases in blood flow and/or decreases in vascular resistance in multiple vascular beds [61]. However, in anaesthetized rats, intravenous olcegepant (a CGRP receptor antagonist) produced no change in baseline mean arterial blood pressure [62]. Furthermore, in healthy humans $[63,64]$, or in humans
TABLE 2: Physiological functions of CGRP in humans and rodents.

\begin{tabular}{|c|c|c|}
\hline Function & Species & Tissue [reference] \\
\hline \multirow{5}{*}{ Vasodilatation } & \multirow{2}{*}{ Rat } & Vascular bed $[14,22]$ \\
\hline & & Kidney [23] \\
\hline & \multirow{3}{*}{ Human } & Cerebral arteries [24] \\
\hline & & $\begin{array}{l}\text { Middle meningeal artery } \\
{[25]}\end{array}$ \\
\hline & & $\begin{array}{c}\text { Artery segments from } \\
\text { thymus [26] }\end{array}$ \\
\hline \multirow[b]{2}{*}{ Inotropic positive effects } & Human & Myocardium [27] \\
\hline & Rat & $\begin{array}{c}\text { Ventricular } \\
\text { cardiomyocytes [28] }\end{array}$ \\
\hline Ingest inhibition & Rat & In vivo [29] \\
\hline Antiproliferative & Rat & $\begin{array}{c}\text { Cellular culture (smooth } \\
\text { muscle) [30] }\end{array}$ \\
\hline $\begin{array}{l}\text { Suppression of aldosterone } \\
\text { release }\end{array}$ & Rat & $\begin{array}{c}\text { Zona glomerulosa cells } \\
{[31]}\end{array}$ \\
\hline \multirow{2}{*}{ Thermal hyperalgesia } & \multirow{2}{*}{ Mouse } & Skin [32] \\
\hline & & Spinal cord [32] \\
\hline
\end{tabular}

with coronary artery disease [65], CGRP receptor antagonists do not seem to have significant effects; thus, CGRP does not seem to play a primary role in the regulation of basal blood pressure (see Section 7, "Final considerations about the relevance of CGRPergic transmission on blood pressure regulation"). Admittedly these studies were performed under a single administration or during a short treatment period.

In this regard, the recent advent of monoclonal antibodies against CGRP will shed further light on this issue [66]. Indeed, two two-phase studies $[67,68]$, showed that subcutaneous administration of TEV-48125 (an antibody against CGRP) given once every month for 3 months for treatment of either high-frequency episodic (297 participants) or chronic 


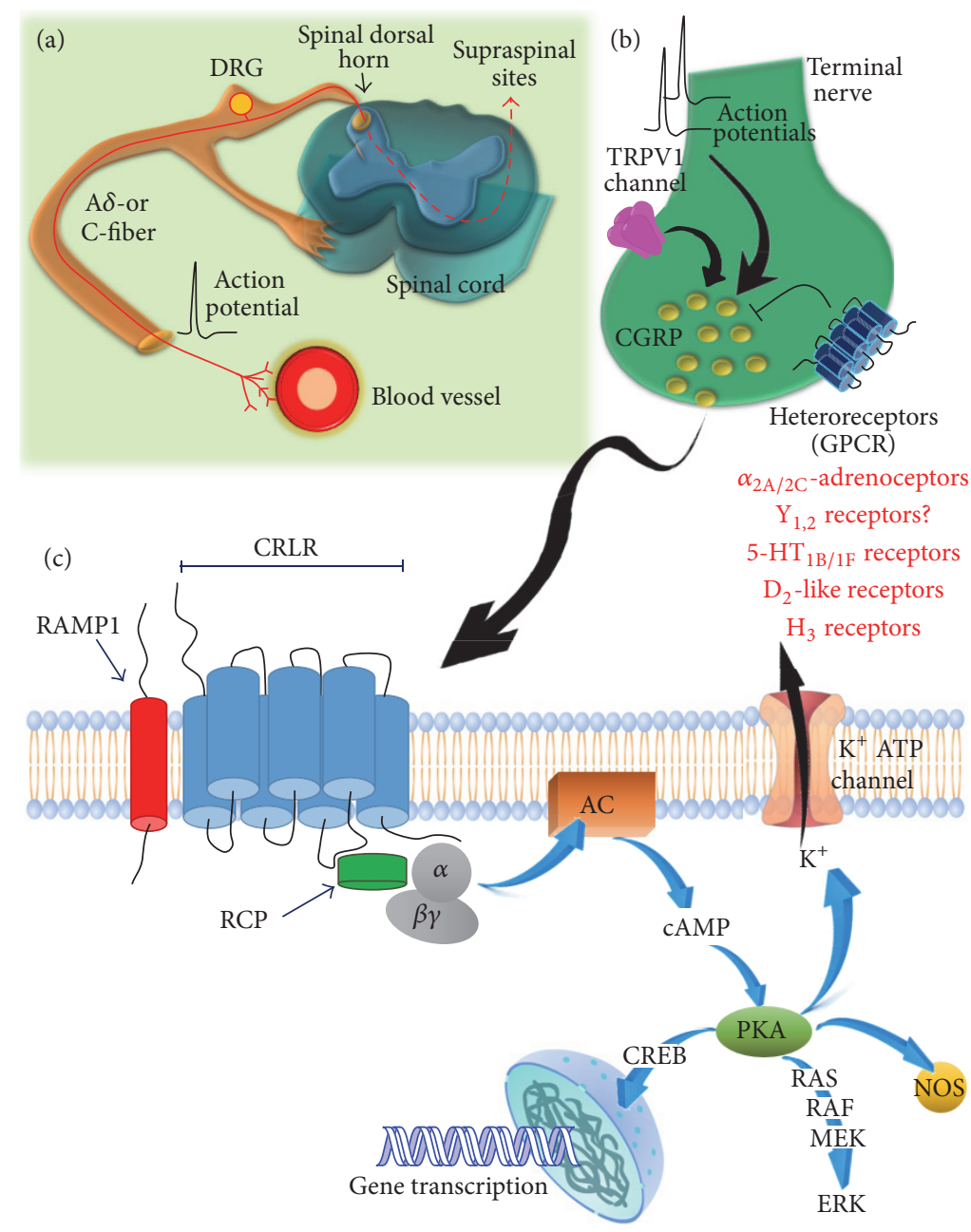

FIGURE 3: CGRPergic neurotransmission at the vascular level. (a) CGRPergic sensory neurons play an important role in the modulation of vascular tone. Indeed, CGRP (from perivascular sensory neurons) can be released from primary afferent fibers. Certainly, CGRP can be also released after activation of TRPV1 channels by capsaicin; if this stimulation is strong enough, an antidromic conduction may be induced and probably also an axonal reflex. Furthermore, a strong stimulus in the periphery could reach the spinal dorsal horn by PAF and consequently could be sent to supraspinal sites. (b) The CGRP release induced by antidromic stimulation, axonal reflex, or activation of TRPV1 channels can be modulated by several heteroreceptors. Most of the heteroreceptors are described as GPCR. Certainly, prejunctional activation of $\alpha_{2 \mathrm{~A} / 2 \mathrm{C}^{-}}$ adrenoceptors, 5- $\mathrm{HT}_{1 \mathrm{~B} / \mathrm{F}}, \mathrm{D}_{2}$-like, $\mathrm{H}_{3}$, and probably $\mathrm{Y}_{1 / 2}$ receptors inhibits the CGRPergic neurotransmission in the systemic vasculature. These heteroreceptors are coupled to $\mathrm{G}_{\mathrm{i} / \mathrm{o}}$ proteins and activation of this system is classically related to inhibition of neurotransmitter release. It is interesting to note that activation of $\alpha_{2 \mathrm{~A} / 2 \mathrm{C}}$-adrenoceptors and $\mathrm{Y}_{1 / 2}$ receptors supports the role of the sympathetic nerves modulating CGRPergic transmission by noradrenaline and neuropeptide Y (a cotransmitter of sympathetic nerves). (c) At cellular level, the responses to CGRP are mainly mediated by an increase in cAMP by activation of CGRP receptors coupled to $\mathrm{G}_{\mathrm{s}} \alpha$ proteins. This atypical receptor belongs to the metabotropic GPCR superfamily and to be functional the CGRP receptor are composed of tree proteins forming a CRLR-RAMP1RCP complex. At vascular level, the increase in cAMP induces vasorelaxation by a direct (vascular smooth muscle cell) and indirect $\left(\mathrm{K}^{+}{ }_{\text {ATP }}\right.$ channels) effect. Furthermore, the NOS pathway can be activated. In addition, recruitment of several intracellular signaling involving ERKs or CREBs may be related to the fact that CGRP has protective properties by attenuation of vascular smooth muscle proliferation, hyperplasia inhibition, and stimulation of endothelial cell proliferation. AC, adenylyl cyclase; cAMP, cyclic adenosine monophosphate; CGRP, calcitonin gene-related peptide; CRLR, calcitonin receptor-like receptor; CREB, cAMP response element-binding protein; GPCR, G-protein-coupled receptors; ERKs, extracellular signal-related kinases; $\mathrm{K}_{\text {ATP }}^{+}$, ATP-sensitive potassium channel; NOS, nitric oxide synthase; PAF, primary afferent fibers; PKA, protein kinase A; RAMP1, receptor activity-modifying protein 1; RCP receptor component protein; TRPV1, transient receptor potential vanilloid 1 .

(264 participants) migraine was effective and safe (with no hemodynamic or cardiovascular changes being recorded). Nevertheless, in addition to the small number of participants, there was no longer duration of follow-up of the participants after the last dose of TEV-48125. Therefore, no definitive conclusions can be drawn regarding the potential for cardiovascular side effects in the longer term (i.e., for longer than 3 months).

Currently, the cardiovascular effects related to a longterm blockade of the CGRP system are unknown and studies 
regarding this issue (a long-term disruption of the CGRPergic system) maybe in large clinical trials (e.g., phase IV studies) could unmask potential vascular unwanted effects. Notwithstanding, under pathophysiological conditions, CGRP has protective properties in cardiovascular disease [69], by attenuation of vascular smooth muscle proliferation [70], hyperplasia inhibition [71], and stimulation of endothelial cell proliferation or endothelial progenitor cells [72].

Moreover, considering the selective perivascular CGRP innervation in some vascular beds [44], it is reasonable to suggest that CGRPergic fibers (apart from mediating a potent vasodilatation) could produce local effects (without reaching plasma). Furthermore, in pathological conditions where plasma CGRP levels are increased (such kidney dialysis), it is possible that CGRP is acting as a compensatory mechanism [73] or to produce a protective effect against myocardial infarction [69]. Since the vascular system is innervated by perivascular sympathetic and sensory nerves, both systems interact controlling the vascular tone, the first one by inducing a vasoconstrictor tone whereas the activation of peptidergic sensory nerves induces vasodilatation mediated by CGRP (which is considered a potent arterial and venous vasodilator).

The role of CGRP on sensory vasodilatation was elegantly demonstrated in a series of experiments performed by Kawasaki et al. [13]. Using the mesenteric resistance blood vessels of the rat under a continuous infusion of methoxamine (a $\alpha_{1}$-adrenoceptor agonist) and guanethidine (an adrenergic neuronal blocker), electrical stimulation of the periarterial nerves induced a vasodilator response which was (i) of neuronal origin (as it was abolished by pretreatment with tetrodotoxin) and (ii) NANC in nature (as it was unaffected by anticholinergic drugs and $\beta$-adrenoceptor antagonists). In addition, this response was dose-dependently mimicked by exogenous CGRP [13, 61]. Together, these data led to hypothesize that CGRP is a key endogenous neuromediator modulating the vascular tone. This hint was corroborated by the use of the CGRP receptor antagonist, $\mathrm{CGRP}_{8-37}$, and an antibody against the CGRP receptor $[14,22]$.

Furthermore, using the pithed rat model under the pharmacological conditions used by Kawasaki et al. [13] (i.e., autonomic blockade and artificial vasoconstriction), Taguchi et al. [74] showed that selective electrical stimulation of the spinal $\mathrm{T}_{9}-\mathrm{T}_{12}$ segments evoked frequency-dependent vasodepressor responses without affecting the heart rate. These electrically induced vasodepressor responses (mimicked by CGRP, but not by SP, acetylcholine, or isoproterenol [a $\beta$ adrenoceptor agonist]) were (i) abolished by tetrodotoxin; (ii) resistant to blockade by atropine (a muscarinic agonist), propranolol (a $\beta$-adrenoceptor antagonist), or the combination of pyrilamine plus cimetidine $\left(\mathrm{H}_{1}\right.$ and $\mathrm{H}_{2}$ receptor antagonists, resp.); (iii) markedly inhibited by capsaicin pretreatment (in order to destroy sensory neurons); and (iv) completely blocked by the antagonist $\mathrm{CGRP}_{8-37}$ (at doses equally blocking the vasodepressor responses to exogenous CGRP). Together, these data showed that the neurogenic vasodepressor (i.e., systemic vasodilator) responses induced in pithed rats are mainly mediated by CGRP release from perivascular sensory nerves [74]. In direct connection with this, there is evidence showing that sensory CGRPergic nerves innervate perivascularly the rat mesenteric arterial bed [13].

5.2. Mechanisms Involved in the Vasodilator Responses to CGRP. At cellular level, the vasodilator responses to CGRP are mainly mediated by an increase in cyclic adenosine monophosphate (cAMP) [45]. At vascular level, CGRP exerts its vasodilator effects by endothelial-dependent [75-78] and endothelial-independent mechanisms [79] (Figure 4). In general, the increase in cAMP reflects the fact that CGRP receptors are coupled to $G_{s} \alpha$ proteins, although the role of $\mathrm{G}_{\mathrm{q} / 11} \alpha$ (with the consequent activation of phospholipase $\mathrm{C}$, PLC) has been suggested $[80,81]$. On this basis, the increase in cAMP induces vasorelaxation by a direct effect, an effect favored by the activation of the ATP-sensitive potassium channels ( $\mathrm{K}^{+}$ATP channel) [82]. This vasodilator mechanism is achieved in several blood vessels with the exception of the aorta and pulmonary artery (where the vasodilator effect is endothelial-dependent). In this case, the response is attenuated by endothelial nitric oxide synthase (eNOS) inhibitors [77, 78, 83], suggesting that the endotheliuminduced vasodilatation is mediated by activation of guanylyl cyclase. In fact, an increase in cAMP in endothelial cells favors the activity of eNOS leading to an increase in nitric oxide (NO). Certainly, the activation of eNOS is mediated by activation of protein kinase A (PKA) [84], but it also could be activated by $\mathrm{G}_{\mathrm{q} / 11} \alpha$ proteins [60].

5.3. CGRPergic Neurotransmission and Interactions with "Hypertensive" Systems. The role of CGRPergic neurotransmission in the modulation of other systems related to the control of cardiovascular function has been demonstrated, particularly with the renin-angiotensin-aldosterone system (RAAS) and the sympathetic nervous system.

In the specific case of the RASS, CGRP inhibits aldosterone secretion induced by angiotensin II (Ang II) [85, 86], suggesting an interaction between these two systems. This idea has been reinforced since, in neonate rats, pretreatment with capsaicin (at doses that destroy the sensory peptidergic fibers) enhanced the induction of hypertension by a high sodium diet [87]. In this case, the mechanism involved is related to suppression of control of the renin-aldosterone secretion [87-90]. Furthermore, in CGRP knockout mice, an increase of the RASS is observed, supporting the above hypothesis [91]. Finally, in perfused mesenteric vascular beds, activation of Ang II receptors inhibits the vasodilatation induced by CGRP release [92]. This effect is probably mediated by a prejunctional (on the sensory perivascular nerves) activation of Ang II type 1 receptor (AT1) [93], since the long-term blockade by losartan (an AT1 receptor preferring antagonist) in spontaneously hypertensive rats (SHR) prevents the reduction of the CGRPergic neurotransmission [92]. In the case of the sympathetic nervous system, the destruction of sensory nerves by capsaicin or the blockade of CGRP receptors by $\mathrm{CGRP}_{8-37}$ enhanced the vasoconstriction induced by noradrenaline without modifying its release [9496], suggesting that the antihypertensive effect of CGRP is lost. 


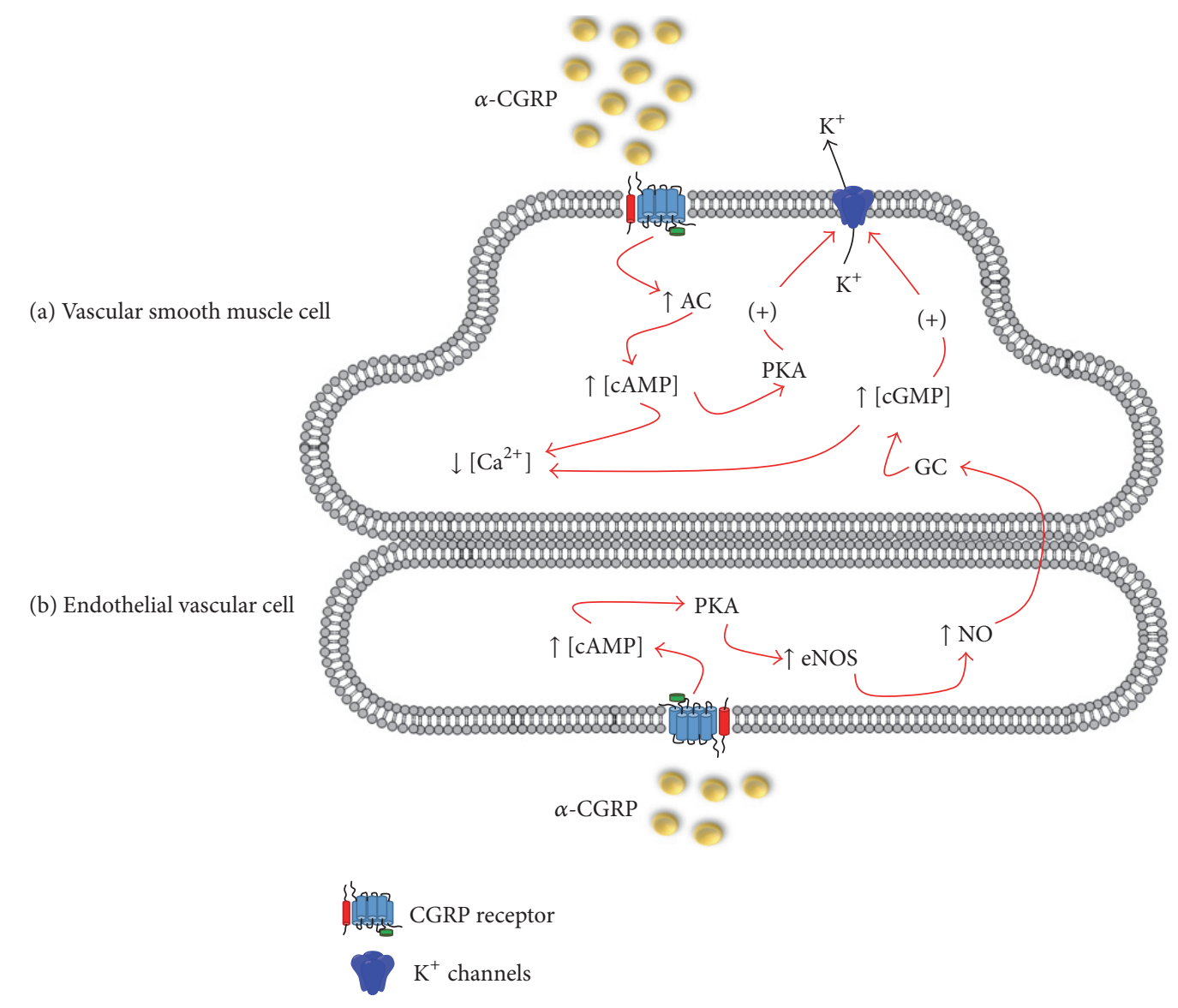

FIGURE 4: Cellular mechanisms involved in the CGRP-induced vasodilation. The vasodilation induced by $\alpha$-CGRP is mediated by activation of the CGRP receptor, a seven-transmembrane domain receptor coupled generally to a $\mathrm{G}_{\mathrm{s}}$ protein that under activation induces the activity of adenylate cyclase. The $\alpha$-CGRP induce vasodilation by two mechanisms: a direct effect on the smooth vascular muscle (a) and by endothelialdependent mechanism (b).

5.4. CGRP Release Modulation at the Neurovascular Junction in the Mesenteric and Systemic Vasculature. Since CGRP seems to play a pivotal role modulating the vascular tone, several mechanisms/receptors have been described to be involved in the modulation of the release of this neuropeptide. Indeed, this CGRPergic neurotransmission could be modulated by heteroreceptors (inhibiting or enhancing the CGRPergic outflow) [94] and autoreceptors (inhibiting the CGRP release) [97] at prejunctional sensory level. In this context, it is interesting to point out that most of the heteroreceptors involved belong to the G-protein-coupled receptors (GPCR) which, among other functions, are classically related to the presynaptic modulation of the neuronal input [98]. Briefly, activation of a $G_{s}$ protein promotes the release of a neuromediator whereas a $G_{i / o}$ inhibits such release.

One of the first evidence showing that CGRP release from sensory perivascular nerves could be modulated by others systems was observed in the mesenteric resistance bed. In this case, Kawasaki et al. [94] showed that neurogenic CGRPergic vasodilation induced by periarterial stimulation was smaller when the vessels where precontracted with NE (a nonselective $\alpha_{1}$ - and $\alpha_{2}$-adrenoceptor agonist) instead of methoxamine (a selective $\alpha_{1}$-adrenoceptor agonist). These results not only suggest that activation of $\alpha_{2}$-adrenoceptor inhibits the CGRP release but also point out the role of sympathetic adrenergic nerves modulating the sensory vasodilator function. Indeed, Supowit et al. [99] showed that UK 14,204 (an $\alpha_{2}$-adrenoceptor agonist) inhibits the CGRP expression in DRG neurons. However, we need to keep in mind that $\alpha_{2}$-adrenoceptors exist in three pharmacologically and structurally subtypes, namely, $\alpha_{2 \mathrm{~A}^{-}}, \alpha_{2 \mathrm{~B}^{-}}$ , and $\alpha_{2 \mathrm{C}}$-adrenoceptors all coupled to $\mathrm{G}_{\mathrm{i} / \mathrm{o}}$ protein [100]. In this context, Villalón et al. [101] showed that CGRPergic neurotransmission is modulated by prejunctional activation of $\alpha_{2 \mathrm{~A}^{-}}$and $\alpha_{2 \mathrm{C}}$-adrenoceptors.

In addition, the sympathetic adrenergic nerves could release other neurotransmitters as cotransmitters (e.g., neuropeptide Y; NPY). Indeed, in perfused mesenteric vascular beds, NPY inhibits the neurogenic release of CGRP $[102,103]$, but the NPY receptor subtype involved remains unknown. Furthermore, perivascular adrenergic nerves could take 5HT and under electrical stimulation this 5-HT could be released producing not only a vasoconstrictor response (by vascular $5-\mathrm{HT}_{2 \mathrm{~A}}$ receptor activation) [104] but also an inhibition of the CGRPergic vasodilatation by inhibition of CGRP release [105]. Certainly, antimigraine drugs such triptans and 
ergots (compounds with high affinity for 5-HT receptors) not only inhibit the neurogenic vasodilation produced by trigeminal release of CGRP at the level of cranial blood vessels (and consequently the dilatation in the headache phase; see Section 6.3) [106-109], but also the CGRPergic systemic vasodilatation [110]. This effect is partly mediated by prejunctional activation of $5-\mathrm{HT}_{1 \mathrm{~B}}$ and $5-\mathrm{HT}_{1 \mathrm{~F}}$ receptors $[111,112]$. In addition, we need to keep in mind that classical drugs for migraine treatment like dihydroergotamine (an ergot) have affinity not only for $5-\mathrm{HT}_{1}$ receptors, but also for (i) $\alpha_{1}$ - and $\alpha_{2}$-adrenoceptors; (ii) $5-\mathrm{HT}_{1}, 5-\mathrm{HT}_{2}, 5-\mathrm{HT}_{5}, 5-$ $\mathrm{HT}_{6}$, and $5-\mathrm{HT}_{7}$ receptors; and (iii) $\mathrm{D}_{2}$-like receptors.

In this sense, prejunctional activation of sensory 5$\mathrm{HT}_{7}$ receptors can also inhibit the release of CGRP by an endothelium-dependent mechanism since the inhibition induced by AS-19 (a 5- $\mathrm{HT}_{7}$ receptor agonist) was blocked not only by pimozide (5- $\mathrm{HT}_{7}$ receptor antagonist), but also by sulfisoxazole (an $\mathrm{ET}_{\mathrm{A}}$ receptor antagonist) [113]. Furthermore, prejunctional $\mathrm{D}_{2}$-like receptors inhibit the CGRPergic outflow in the systemic vasculature [114]. These data may be of particular relevance when considering potential cardiovascular side effects by antimigraine drugs as previously suggested [110].

Since histamine can be released from adrenergic nerves in the mesenteric bed [115], the potential role of histamine $(\mathrm{H})$ receptors has been investigated. In this case, histamine plays a dual role on the CGRP release where prejunctional activation of $\mathrm{H}_{3}$ receptors inhibits the neurogenic vasodilation [116, 117], whereas $\mathrm{H}_{2}$ receptors enhance the CGRP nerve-mediated vasodilation possible by an enhancement of prejunctional activity of TRPV1 receptors [118]. In any case, these pro- and antivasodilator effects by the same molecule could reflect a fine tuning of the CGRP release by the sympathetic nerves.

Finally, a complex interaction between the ANS and the sensory nerves modulating vascular tone has been described. Presynaptic activation of nicotinic ACh receptors in the perivascular adrenergic nerves is able to release protons $\left(\mathrm{H}^{+}\right)$ as a cotransmitter which in turn is able to activate TRPV1 receptors in the sensory nerves and consequently the release of CGRP [119, 120] suggesting a paracrine control of the vascular tone [121]. In addition, it is widely documented that sex steroid hormones regulate several biological functions [122] and in ovariectomized rats treatment for $1-3$ weeks with $17 \beta$-estradiol potentiated the CGRP-induced relaxation in the mesenteric, caudal arteries [123], and the middle meningeal artery (a vessel involved in the pathophysiology of migraine) [124]. These results could explain (at least partially) the fact that hypertension is more common in men than women and why migraine is more common in women.

\section{The Role of CGRP on Some Vascular- Related Diseases}

6.1. CGRP and Hypertension. Hypertension or high blood pressure (a persistently high value at/or above 140/90 $\mathrm{mm} \mathrm{Hg}$ ) is a major worldwide health problem and can be classified as primary or essential hypertension (due to nonspecific lifestyle and genetic factors) and secondary hypertension (due to an identifiable cause) [125]. This pathology is ranked as the third cause of age-dependent disability (its prevalence is higher in older adults) [126]. Furthermore, both primary hypertension and secondary hypertension are considered a risk factor for cardiovascular associated diseases (stroke, heart failure, peripheral vascular disease, vision loss, etc.) [127]. Despite all these important facts, the mechanisms involved in the onset of hypertension remain unclear.

Using experimental models of hypertension, it has been reported that CGRP-containing nerves in mesenteric arteries are decreased [128]. In addition, capsaicin-induced hypertension can be mediated by decreased vasodilatation (CGRP, kinin, or prostaglandin) or by a direct action on vascular smooth muscle [129]. There is increased evidence that the sensory nervous system plays an important role in experimental hypertension [5, 130-133]. For example, CGRP administration may significantly decrease high blood pressure in humans [134] and early reports demonstrated that CGRP attenuated chronic hypoxic pulmonary hypertension [135]. In addition, one genetic study has shown that CALC I (a gene that encodes CGRP and calcitonin) is associated with a polymorphism that is maybe correlated to essential hypertension susceptibility [136]. However, this was a small study and the functional significance of this polymorphism is not yet known.

Certainly, Mai et al. [131] showed in $\alpha$-CGRP knockout mice an increase in mean arterial pressure (using telemetry), an effect due to an enhancement of the sympathetic discharge, as previously suggested [137], supporting the hypothesis that CGRPergic nerves modulate the sympathetic activity [16]. However, this increase in blood pressure contrasts with the findings reported by Smillie et al. [138], who found that basal blood pressure in wild-type and $\alpha$-CGRP knockout mice are similar (using the tail cuff method). Thus, the CGRPergic system seems to play a protective role against hypertension, vascular hypertrophy, and oxidative stress induced by angiotensin II [138]. It is important to point out two key experimental differences between these contrasting studies: (i) Mai et al. [131] used a global knockout $\alpha$-CGRP/calcitonin mice whereas Smillie et al. [138] used a selective $\alpha$-CGRP knockout mice and (ii) the method to measure blood pressure, that is, telemetry (a continuous recording of blood pressure) against tail cuff method (one measure at one time in a day). Certainly, as reported by Mai et al. [131], the mean arterial pressure in the $\mathrm{CGRP}^{-/-}$mice was not significant at any individual 12-hour data point (as reported by Smillie et al. [138]); however, the global average daytime was significantly higher in these knockout mice, suggesting that, in addition to the transgenic mice used, the method and protocol to measure blood pressure could be relevant to find differences. In any case, both studies support the notion that sensory CGRPergic nerves could be acting as a protective system modulating the activity of "hypertensive" systems as observed in other hypertension animal wild-type models $[45,130,139]$.

Although exogenous administration of $\alpha$-CGRP in healthy humans decreases blood pressure, one important issue about the role of CGRPergic neurotransmission in the development of hypertension remains unclear, in part because plasma concentrations of CGRP are inconsistent $[126,130,139]$. In this case, the heterogeneous results may be 
due to the compensatory mechanisms involved at the stage that the plasmatic concentration is measured. For example, some studies have shown a decrease [134], an increase [140], or no change in plasma CGRP concentrations [141]. Moreover, in $\alpha$-CGRP knockout mice, SHR, dahl-salt, or phenol-induced hypertension, a decrease in plasma CGRP is observed [32, 35, 142, 143], whereas in models like Doc-salt or blockade of $\mathrm{NO}$ activity by $\mathrm{N} \omega$-nitro-L-arginine methyl ester (L-NAME) the plasma levels of CGRP are enhanced [144146] (for an extensive detail about CGRP and hypertension see $[126,139])$.

In addition, some data seem to support the role of CGRP during hypertension. For example, chronic administration of captopril reverses the reduced CGRPergic responses, at least in SHR [147] where the function of CGRP is reduced [148]. Furthermore, it has been shown that chronic hyperinsulinemia (a condition associated with hypertension) not only enhances adrenergic vasoconstriction, but also decreases the CGRPergic function [149-151] and the use of pioglitazone (an antihyperglycemic drug used in diabetics) can restore the sensory nerve-induced vasodilation by CGRP release [152]. Indeed, acute hyperglycemia and hyperinsulinemia have been associated with an increase of the sympathetic vasoconstrictor function and a decrease of the CGRPergic vasodilation [153]. Certainly, the role of CGRP in hypertension seems to be relevant, but future research on the potential use of a compound to treat this disorder remains a challenge.

6.2. CGRP and Preeclampsia. Preeclampsia (PE), a pregnancy-specific syndrome affecting $3-5 \%$ of pregnancies, is one of the main causes of maternal, fetal, and neonatal mortality [154-156] and is associated with an increased risk to develop cardiovascular disease and stroke in the future $[157,158]$. Though the pathogenesis of PE still remains poorly understood, this disorder is characterized by an increase of maternal blood pressure (beginning during the 1st trimester) and proteinuria [154], and strong evidence suggests that disturbances in placentation leading to generalized inflammation and progressive endothelial damage are one of the major causes of PE $[159,160]$. Certainly, PE is a multisystemic syndrome characterized by increased vascular resistance ( $>140 />90 \mathrm{~mm} \mathrm{Hg}$ on two occasions that are 4-6 h apart).

Apart from the delivery as the cure for PE, the use of antihypertensive drugs ( $\alpha$-adrenoceptors agonists, $\beta$-blockers, $\mathrm{Ca}^{2+}$ channels blockers, vasodilators, ketanserin, and glyceryl trinitrate) to stabilize the blood pressure is the currently used pharmacotherapy (see the WHO guidelines, [132]). Certainly, the increase in blood pressure in preeclampsia is associated with (i) an increase in the plasma concentrations of vasoconstrictor agents such as thromboxane and prostacyclins [161], serotonin [162], and noradrenaline [163]; (ii) a decrease in the plasma concentrations of vasodilator agents such as CGRP and ADM [164, 165]; and (iii) an increase in vascular reactivity to Ang II [166]. In this context, it has been suggested that CGRP plays a key role in the control of human fetoplacental vascular tone [167] and it is interesting to note that two components of the CGRP receptor (CRLR and RAMP1) are expressed (mRNA) in fetoplacental vessels (umbilical artery and vein, chorionic artery and vein) [168].
Interestingly, during PE, the expression of CRLR and RAMP1 is reduced in these vessels [168] suggesting a disruption of CGRPergic vasodilator function.

With this in mind, Yallampalli et al. [169] showed that, in animals with PE-like condition, where the hypertension during pregnancy was induced by chronic inhibition of NO with L-NAME, coadministration of CGRP prevented not only the L-NAME-induced hypertension, but also the pup mortality. Furthermore, since blockade of CGRP receptor with $\mathrm{CGRP}_{8-37}$ enhances the L-NAME-induced hypertension, a compensatory vasodilator effect of CGRP is supported [144]. This hypothesis is reinforced by the fact that, in humans, CGRP levels in umbilical cord blood are increased in PE [170] probably to counteract the reduction in the CRLR and RAMP1 proteins in the chorionic plate [165] and the fetoplacental vessels [168]. However, other studies in pregnant women found that the plasmatic levels of CGRP (in maternal serum or umbilical serum) are diminished in the PE patients [164]. Although, this difference could be due to the site of sample extraction, tissue, and technique used to measure CGRP, these studies point out the potential relevance of CGRPergic neurotransmission during PE [171].

An interesting finding about the role of CGRP in PE was the fact that magnesium sulfate $\left(\mathrm{MgSO}_{4}\right)$ therapy (a standard treatment to avoid eclampsia, a serious complication of $\mathrm{PE}$ ) can modulate several molecules implicated in PE, including CGRP, ADM, the angiogenic factor of soluble intracellular adhesion molecule-1 (sICAM-1), and the prooxidant factor of total homocysteine (hHcy) [172]. In this sense, $\mathrm{MgSO}_{4}$ increased CGRP levels in the maternal circulation $[164,173]$ and the CRLR and RAMP1 components in the placental tissue [174]. More recently, it has been suggested that maternal circulating CGRP could serve as a biomarker for early detection of PE [175].

In summary, these findings may have important clinical implications in view that CGRP may contribute to the low fetoplacental vascular resistance in normal pregnancies, and CGRP-dependent vascular relaxation appears to be compromised during $\mathrm{PE}$.

6.3. CGRP and Migraine. Migraine is a complex neurovascular disorder $[176,177]$ associated with disturbances in the CGRPergic system at trigeminal level (for references see [52]). The neurobiology behind migraine involves the role of CGRP and its receptors which are highly expressed in the trigeminovascular system [178]. Current stablished or potential pharmacotherapy to treat migraine attacks includes the use of triptans (e.g., sumatriptan), ergots (e.g., dihydroergotamine), gepants (e.g., olcegepant), and more recently nezumabs (antibodies against CGRP) $[179,180]$. Triptans and ergots inhibit CGRP release at peripheral (on vasculature) and central level, whereas gepants prevent the actions of CGRP by blocking the CGRP receptors [52] and nezumabs by acting as CGRP scavengers [180].

At peripheral level, the trigeminal nerve innervates several tissues in the head by three branches: (i) ophthalmic, (ii) maxillary, and (iii) mandibular [181]. The ophthalmic branch senses information from the blood vessels which irrigate meninges [182]. Furthermore, blood vessels from 
dura mater are rich in expressing CGRP receptors, specifically on the smooth muscle cells [183]. Hence, expression of CGRP receptors at the peripheral level seems to be mainly postjunctional. Moreover, experimental hyperactivation of sensory fibers innervating dura mater in animal models induces neurogenic vasodilation (mediated by CGRP) and plasma protein extravasation (PPE) (mediated by tachykinins and endothelins); both components are related to the "neurogenic inflammation theory of migraine" [184]. Although in animal models both conditions seem to participate in sensitization of nociceptors and subsequently hyperalgesia, only blockade of the neurogenic vasodilation [185], but not of PPE [184] was effective in the acute treatment of migraine. In addition, the action mechanism of some prophylactic drugs seems to be related to the inhibition of CGRP release at the perivascular level since in a migraine animal model fluoxetine administration (for 3 weeks) inhibits the capsaicin-induced vasodilatation [186]. These results point out the relevance of CGRPergic transmission in the trigeminovascular system during migraines.

More recently, Vilotti et al. [187] reported that experimental mutations in $\mathrm{Ca}_{\mathrm{v}} 2.1 \mathrm{Ca}^{2+}$ channels in mice (altered in familial hemiplegic migraineurs) result in higher release of CGRP rather than changes in CGRP receptor expression. Hence, peripheral release of CGRP (which induces vasodilatation) into the trigeminovascular system is regulated by several mechanisms of neuromodulation at the neurovascular junction and almost all these systems and receptors are also modulating the afferent input to the trigeminal nucleus [188]. Examples of the above are the ergots $\left(5-\mathrm{HT}_{1}\right.$, $\alpha_{2}$-adrenergic, and $\mathrm{D}_{2}$-like receptor agonists) and triptans (selective $5-\mathrm{HT}_{1 \mathrm{~B} / 1 \mathrm{D} / 1 \mathrm{~F}}$ receptor agonist) $[186,189-191]$. In fact, treatments to specifically block the function of CGRP receptors are the targets of the pharmacological therapies under clinical review which promise to decrease the side effects of classic antimigraine drugs (i.e., cardiovascular effects). However, the potential risk for unmasking and/or boosting hypertensive mechanisms is a topic that needs to be deeply explored as previously suggested [66, 110]. Indeed, LY2951742 (antibody against CGRP) administration potently inhibited the capsaicin-induced dermal blood flow [192], suggesting that these compounds can block the systemic CGRPergic system (for more detailed information on antibodies against CGRP see $[66,132])$.

\section{Final Considerations about the Relevance of CGRPergic Transmission on Blood Pressure Regulation}

Regarding the use of animal experimental models, an intact or even an anaesthetized animal should be a closer model for assessing the physiological importance of olcegepant's (CGRP receptor antagonist, an antimigraine compound) actions. Indeed, intravenous administration of $3 \mathrm{mg} / \mathrm{kg}$ olcegepant, which markedly blocked the vasodepressor responses to CGRP in anaesthetized rats, produced no change in baseline mean arterial blood pressure [51]. These results, in addition to indicating that exogenous CGRP produces systemic vasodilatation by activation of CGRP receptors, might suggest that endogenously produced CGRP does not play an important role in modulating both the systemic vascular tone and blood pressure under physiological conditions. However, some aspects of the haemodynamic actions of CGRP and CGRP receptor antagonists can be detected only in the absence of central reflexes, as in pithed rats. In this respect, $3 \mathrm{mg} / \mathrm{kg}$ olcegepant (IV) in pithed rats, which abolished the vasodepressor sensory CGRPergic outflow and the vasodepressor responses to exogenous CGRP, potentiated the neurogenic (perivascular sympathetic) and nonneurogenic (by exogenous noradrenaline) vasopressor responses, an effect that might result in a prohypertensive action [193].

The above findings suggest that, in intact or anesthetized rats, central reflexes (e.g., the baroreceptor reflex) might be compensating for the changes in blood pressure and/or heart rate produced by olcegepant. If these changes occur chronically (e.g., when taking olcegepant frequently), they may result in cardiovascular disease. Consistent with the above suggestions, blood pressure determined by telemetry was increased in unrestrained CGRP knockout mice [91, 131]. However, Lu et al. [194] found no difference in the systemic blood pressure of $\alpha$-CGRP knockout mice, but blood pressure was measured with a catheter inserted into the carotid artery and recorded for $2 \mathrm{~min}$ of integration time. These apparent discrepancies most probably reflect differences in the experimental conditions.

\section{Final Remarks}

The CGRPergic system seems to exert a significant effect on the modulation of vascular tone. Endogenous CGRP released from PAF is a potent vasodilator. Certainly, CGRP and its receptor have emerged as an interesting target involved in vascular tone modulation under physiological conditions and during some vascular-related diseases. The increasing understanding in the receptors/mechanisms involved in regulation of CGRP release under normal or pathological conditions suggests that the CGRP receptor should be considered as a relevant target in the development of therapeutic alternatives to treat pathologies related to the cardiovascular system as hypertension (agonists), preeclampsia (agonists), and migraine (antagonists).
Abbreviations
AC: Adenylyl cyclase
ACh: Acetylcholine
ADM: Adrenomedullin
Ang II: Angiotensin II
ANS: Autonomic nervous system
AT1: Angiotensin II receptor type 1
ATP: Adenosine triphosphate
cAMP: Cyclic adenosine monophosphate
CREB: cAMP response element-binding protein
CRLR: Calcitonin receptor-like receptor 
cGMP: Cyclic guanosine monophosphate

CGRP: $\quad$ Calcitonin gene-related peptide

CNS: Central nervous system

DRG: Dorsal root ganglia

eNOS: $\quad$ Endothelial nitric oxide synthase

ERKs: $\quad$ Extracellular signal-related kinases

$\mathrm{ET}_{\mathrm{A}}$ : $\quad$ Endothelin receptor type A

GPCR: G-protein-coupled receptor

hHcy: $\quad$ Prooxidant factor of total homocysteine

$\mathrm{IP}_{3}$ : $\quad$ Inositol 1,4,5-triphosphate

IUPHAR: International Union of Basic and Clinical Pharmacology

$\mathrm{K}^{+}{ }_{\text {ATP }}$ channel: ATP-sensitive potassium channels

$\mathrm{K}^{+} \mathrm{Ca}^{2+}$ channel: Calcium-activated potassium channels

L-NAME: $\quad \mathrm{N} \omega$-nitro-L-arginine methyl ester

$\mathrm{MgSO}_{4}: \quad$ Magnesium sulfate

$\mathrm{NA}$ :

NANC:

NO:

NPY:

PAF:

PE:

PGs:

PKA:

PKC:

PLC:

PNS:

PPE:

RAMP1:

RASS:

RCP:

SHR:

sICAM-1:

SP:

TRPV1:

VIP:

\section{Competing Interests}

The authors declare no conflict of interests.

\section{Acknowledgments}

The authors are grateful to all their colleagues who collaborated in the studies cited in this review.

\section{References}

[1] S. Boehm and H. Kubista, "Fine tuning of sympathetic transmitter release via ionotropic and metabotropic presynaptic receptors," Pharmacological Reviews, vol. 54, no. 1, pp. 43-99, 2002.

[2] M. J. Mulvany and C. Aalkjaer, "Structure and function of small arteries," Physiological Reviews, vol. 70, no. 4, pp. 921-961, 1990.

[3] A. Rubino and G. Burnstock, "Capsaicin-sensitive sensorymotor neurotransmission in the peripheral control of cardiovascular function," Cardiovascular Research, vol. 31, no. 4, pp. 467-479, 1996.
[4] M. R. Bennett, "Non-adrenergic non-cholinergic (NANC) transmission to smooth muscle: 35 years on," Progress in Neurobiology, vol. 52, no. 3, pp. 159-195, 1997.

[5] B. F. King, "Purinergic signalling in the enteric nervous system (an overview of current perspectives)," Autonomic Neuroscience: Basic \& Clinical, vol. 191, pp. 141-147, 2015.

[6] M. J. Rand, "Nitrergic transmission: nitric oxide as a mediator of non-adrenergic, non-cholinergic neuro-effector transmission," Clinical and Experimental Pharmacology and Physiology, vol. 19, no. 3, pp. 147-169, 1992.

[7] G. Burnstock, G. Campbell, D. Satchell, and A. Smythe, "Evidence that adenosine triphosphate or a related nucleotide is the transmitter substance released by non-adrenergic inhibitory nerves in the gut," British Journal of Pharmacology, vol. 40, no. 4, pp. 668-688, 1970.

[8] G. Burnstock, "Do some nerve cells release more than one transmitter?" Neuroscience, vol. 1, no. 4, pp. 239-248, 1976.

[9] C. Su, J. A. Bevan, and G. Burnstock, " $\left[{ }^{3} \mathrm{H}\right]$ adenosine triphosphate: Release during stimulation of enteric nerves," Science, vol. 173, no. 3994, pp. 336-338, 1971.

[10] J. B. Furness, J. C. Bornstein, R. Murphy, and S. Pompolo, "Roles of peptides in transmission in the enteric nervous system," Trends in Neurosciences, vol. 15, no. 2, pp. 66-71, 1992.

[11] J. M. Lundberg, "Pharmacology of cotransmission in the autonomic nervous system: integrative aspects on amines, neuropeptides, adenosine triphosphate, amino acids and nitric oxide," Pharmacological Reviews, vol. 48, no. 1, pp. 113-178, 1996.

[12] A. Ahluwalia and P. Vallance, "Interaction between sympathetic and sensory nerves in rat small arteries: involvement of nitric oxide," American Journal of Physiology, vol. 271, no. 3, pp. H969H976, 1996.

[13] H. Kawasaki, K. Takasaki, A. Saito, and K. Goto, "Calcitonin gene-related peptide acts as a novel vasodilator neurotransmitter in mesenteric resistance vessels of the rat," Nature, vol. 335, no. 6186, pp. 164-167, 1988.

[14] S.-P. Han, L. Naes, and T. C. Westfall, "Calcitonin generelated peptide is the endogenous mediator of nonadrenergicnoncholinergic vasodilation in rat mesentery," Journal of Pharmacology and Experimental Therapeutics, vol. 255, no. 2, pp. 423-428, 1990.

[15] D. Bell and B. J. Mcdermott, "Calcitonin gene-related peptide in the cardiovascular system: characterization of receptor populations and their (patho) physiological significance," Pharmacological Reviews, vol. 48, no. 2, pp. 253-288, 1996.

[16] M. V. Donoso, D. Hermosilla, C. Navarrete, P. Álvarez, J. G. Lillo, and J. P. Huidobro-Toro, "Reciprocal sympatho-sensory control: functional role of nucleotides and calcitonin generelated peptide in a peripheral neuroeffector junction," Neuroscience, vol. 203, pp. 216-229, 2012.

[17] W. M. Bayliss, "On the origin from the spinal cord of the vasodilator fibres of the hind-limb, and on the nature of these fibres," The Journal of Physiology, vol. 26, no. 3-4, pp. 173-209, 1901.

[18] F. Breslauer, "The pathogenesis of trophic tissue damage after nerve injury," Deutsche Zeitschrift für Chirurgie, vol. 150, no. 1, pp. 50-81, 1919 (German).

[19] J. Erlanger and H. S. Gasser, "The compound nature of the action current of nerve as disclosed by the cathode ray oscillography," The American Journal of Physiology, vol. 70, pp. 624-666, 1924.

[20] J. Erlanger and H. S. Gasser, "The action potential in fibers of slow conduction in spinal roots and somatic nerves," The American Journal of Physiology, vol. 92, pp. 43-82, 1930. 
[21] S. D. Brain and H. M. Cox, "Neuropeptides and their receptors: innovative science providing novel therapeutic targets," British Journal of Pharmacology, vol. 147, S1, pp. S202-S211, 2006.

[22] S. P. Han, L. Naes, and T. C. Wesfall, "Inhibition of periarterial nerve stimulation-induced vasodilation of the mesenteric arterial bed by $\mathrm{CGRP}_{8--37}$ and CGRP receptor desensitization," Biochemical and Biophysical Research Communications, vol. 168, no. 2, pp. 786-791, 1990.

[23] J. M. Haynes and M. E. Cooper, "Adrenomedullin and calcitonin gene-related peptide in the rat isolated kidney and in the anaesthetised rat: in vitro and in vivo effects," European Journal of Pharmacology, vol. 280, no. 1, pp. 91-94, 1995.

[24] L. Edvinsson, R. Alm, D. Shaw et al., "Effect of the CGRP receptor antagonist BIBN4096BS in human cerebral, coronary and omental arteries and in SK-N-MC cells," European Journal of Pharmacology, vol. 434, no. 1-2, pp. 49-53, 2002.

[25] L. Edvinsson, S. Gulbenkian, C. P. Barroso et al., "Innervation of the human middle meningeal artery: immunohistochemistry, ultrastructure, and role of endothelium for vasomotility," Peptides, vol. 19, no. 7, pp. 1213-1225, 1998.

[26] H. C. Champion, T. J. Bivalacqua, R. L. Pierce et al., "Responses to human CGRP, ADM, and PAMP in human thymic arteries," American Journal of Physiology-Regulatory Integrative and Comparative Physiology, vol. 284, no. 2, pp. R531-R537, 2003.

[27] O. Saetrum Opgaard, P. Hasbak, R. de Vries, P. R. Saxena, and L. Edvinsson, "Positive inotropy mediated via CGRP receptors in isolated human myocardial trabeculae," European Journal of Pharmacology, vol. 397, no. 2-3, pp. 373-382, 2000.

[28] D. Bell and B. J. McDermott, "Calcitonin gene-related peptide stimulates a positive contractile response in rat ventricular cardiomyocytes," Journal of Cardiovascular Pharmacology, vol. 23, no. 6, pp. 1011-1021, 1994.

[29] G. M. Taylor, K. Meeran, D. O’Shea, D. M. Smith, M. A. Ghatei, and S. R. Bloom, "Adrenomedullin inhibits feeding in the rat by a mechanism involving calcitonin gene-related peptide receptors," Endocrinology, vol. 137, no. 8, pp. 3260-3264, 1996.

[30] H. Kano, M. Kohno, K. Yasunari et al., "Adrenomedullin as a novel antiproliferative factor of vascular smooth muscle cells," Journal of Hypertension, vol. 14, no. 2, pp. 209-213, 1996.

[31] P. G. Andreis, G. Mazzocchi, P. Rebuffat, and G. G. Nussdorfer, "Effects of adrenomedullin and proadrenomedullin N-terminal 20 peptide on rat zona glomerulosa cells," Life Sciences, vol. 60, no. 19, pp. 1693-1697, 1997.

[32] J. S. Mogil, F. Miermeister, F. Seifert et al., "Variable sensitivity to noxious heat is mediated by differential expression of the CGRP gene," Proceedings of the National Academy of Sciences of the United States of America, vol. 102, no. 36, pp. 12938-12943, 2005.

[33] S. N. Lawson, "Morphological and biochemical cell types of sensory neurons," in Sensory Neurons, S. A. Scott, Ed., pp. 27-59, Oxford University Press, Oxford, UK, 1st edition, 1992.

[34] J. M. Lundberg, A. Franco-Cereceda, X. Hua, T. Hökfelt, and J. A. Fischer, "Co-existence of substance P and calcitonin generelated peptide-like immunoreactivities in sensory nerves in relation to cardiovascular and bronchoconstrictor effects of capsaicin," European Journal of Pharmacology, vol. 108, no. 3, pp. 315-319, 1985.

[35] P. R. R. Gangula, H. Zhao, S. C. Supowit et al., "Increased blood pressure in $\alpha$-calcitonin gene-related peptide/calcitonin gene knockout mice," Hypertension, vol. 35, no. 1, pp. 470-475, 2000.

[36] H. Yaoita, E. Sato, M. Kawaguchi, T. Saito, K. Maehara, and Y. Maruyama, "Nonadrenergic noncholinergic nerves regulate basal coronary flow via release of capsaicin-sensitive neuropeptides in the rat heart," Circulation Research, vol. 75, no. 4, pp. 780-788, 1994.

[37] A. Franco-Cereceda and J. M. Lundberg, "Post-occlusive reactive hyperaemia in the heart, skeletal muscle and skin of control and capsaicin-pre-treated pigs," Acta Physiologica Scandinavica, vol. 137, no. 2, pp. 271-277, 1989.

[38] D. Julius and A. I. Basbaum, "Molecular mechanisms of nociception," Nature, vol. 413, no. 6852, pp. 203-210, 2001.

[39] M. G. Rosenfeld, J.-J. Mermod, S. G. Amara et al., "Production of a novel neuropeptide encoded by the calcitonin gene via tissue-specific RNA processing," Nature, vol. 304, no. 5922, pp. 129-135, 1983.

[40] S. Hagner, U. Stahl, B. Knoblauch et al., "Calcitonin receptorlike receptor: identification and distribution in human peripheral tissues," Cell and Tissue Research, vol. 310, pp. 41-50, 2002.

[41] F. A. Tschopp, H. Henke, J. B. Petermann et al., "Calcitonin gene-related peptide and its binding sites in the human central nervous system and pituitary," Proceedings of the National Academy of Sciences of the United States of America, vol. 82, no. 1, pp. 248-252, 1985.

[42] P. K. Mulderry, M. A. Ghatei, J. Rodrigo et al., "Calcitonin gene-related peptide in cardiovascular tissues of the rat," Neuroscience, vol. 14, no. 3, pp. 947-954, 1985.

[43] S. G. Amara, J. L. Arriza, S. E. Leff, L. W. Swanson, R. M. Evans, and M. G. Rosenfeld, "Expression in brain of a messenger RNA encoding a novel neuropeptide homologous to calcitonin generelated peptide," Science, vol. 229, no. 4718, pp. 1094-1097, 1985.

[44] S. Gulbenkian, O. Saetrum Opgaard, R. Ekman et al., "Peptidergic innervation of human epicardial coronary arteries," Circulation Research, vol. 73, no. 3, pp. 579-588, 1993.

[45] S. J. Wimalawansa, "Calcitonin gene-related peptide and its receptors: Molecular genetics, physiology, pathophysiology, and therapeutic potentials," Endocrine Reviews, vol. 17, no. 5, pp. 533-585, 1996.

[46] D. R. Poyner and I. Marshall, "CGRP receptors: beyond the $\mathrm{CGRP}_{1}-\mathrm{CGRP}_{2}$ subdivision?" Trends in Pharmacological Sciences, vol. 22, no. 5, p. 223, 2001.

[47] D. R. Poyner, P. M. Sexton, I. Marshall et al., "International Union of Pharmacology. XXXII. The mammalian calcitonin gene-related peptides, adrenomedullin, amylin, and calcitonin receptors," Pharmacological Reviews, vol. 54, no. 2, pp. 233-246, 2002.

[48] J. Roh, C. L. Chang, A. Bhalla, C. Klein, and S. Y. T. Hsu, "Intermedin is a calcitonin/calcitonin gene-related peptide family peptide acting through the calcitonin receptor-like receptor/receptor activity-modifying protein receptor complexes," The Journal of Biological Chemistry, vol. 279, no. 8, pp. 72647274, 2004.

[49] B. A. Marichal-Cancino, A. González-Hernández, G. Manrique-Maldonado et al., "Intrathecal dihydroergotamine inhibits capsaicin-induced vasodilatation in the canine external carotid circulation via GR127935- and rauwolscine-sensitive receptors," European Journal of Pharmacology, vol. 692, no. 1-3, pp. 69-77, 2012.

[50] P. Holzer and C. A. Maggi, "Dissociation of dorsal root ganglion neurons into afferent and efferent-like neurons," Neuroscience, vol. 86, no. 2, pp. 389-398, 1998.

[51] U. Arulmani, A. MaassenVanDenBrink, C. M. Villalón, and P. R. Saxena, "Calcitonin gene-related peptide and its role in migraine pathophysiology," European Journal of Pharmacology, vol. 500, no. 1-3, pp. 315-330, 2004. 
[52] C. M. Villalón and J. Olesen, "The role of CGRP in the pathophysiology of migraine and efficacy of CGRP receptor antagonists as acute antimigraine drugs," Pharmacology and Therapeutics, vol. 124, no. 3, pp. 309-323, 2009.

[53] D. L. Hay, D. R. Poyner, and R. Quirion, "International union of pharmacology. LXIX. Status of the calcitonin gene-related peptide subtype 2 receptor," Pharmacological Reviews, vol. 60, no. 2, pp. 143-145, 2008

[54] C. S. Walker, S. Eftekhari, R. L. Bower et al., "A second trigeminal CGRP receptor: function and expression of the $\mathrm{AMY}_{1}$ receptor," Annals of Clinical and Translational Neurology, vol. 2, no. 6, pp. 595-608, 2015.

[55] L. M. McLatchie, N. J. Fraser, M. J. Main et al., "RAMPs regulate the transport and ligand specificity of the calcitonin-receptorlike receptor," Nature, vol. 393, no. 6683, pp. 333-339, 1998.

[56] K. R. Klein, B. C. Matson, and K. M. Caron, "The expanding repertoire of receptor activity modifying protein (RAMP) function," Critical Reviews in Biochemistry and Molecular Biology, vol. 51, no. 1, pp. 66-71, 2016.

[57] S. M. Foord and F. H. Marshall, "RAMPs: accessory proteins for seven transmembrane domain receptors," Trends in Pharmacological Sciences, vol. 20, no. 5, pp. 184-187, 1999.

[58] I. M. Dickerson, "Role of CGRP-receptor component protein (RCP) in CLR/RAMP function," Current Protein \& Peptide Science, vol. 14, no. 5, pp. 407-415, 2013.

[59] M. Haass and G. Skofitsch, "Cardiovascular effects of calcitonin gene-related peptide in the pithed rat: comparison with substance P," Life Sciences, vol. 37, no. 22, pp. 2085-2090, 1985.

[60] R.-Q. Sun, Y.-J. Tu, N. B. Lawand, J.-Y. Yan, Q. Lin, and W. D. Willis, "Calcitonin gene-related peptide receptor activation produces PKA- and PKC-dependent mechanical hyperalgesia and central sensitization," Journal of Neurophysiology, vol. 92, no. 5, pp. 2859-2866, 2004.

[61] S. M. Gardiner, A. M. Compton, and T. Bennett, "Regional hemodynamic effects of calcitonin gene-related peptide," The American Journal of Physiology, vol. 256, no. 2, pp. R332-R338, 1989.

[62] U. Arulmani, M. P. Schuijt, J. P. C. Heiligers, E. W. Willems, C. M. Villalón, and P. R. Saxena, "Effects of the calcitonin generelated peptide (CGRP) receptor antagonist BIBN4096BS on $\alpha$-CGRP-induced regional haemodynamic changes in anaesthetised rats," Basic and Clinical Pharmacology and Toxicology, vol. 94, no. 6, pp. 291-297, 2004.

[63] J. Olesen, H.-C. Diener, I. W. Husstedt et al., "Calcitonin generelated peptide receptor antagonist BIBN 4096 BS for the acute treatment of migraine," New England Journal of Medicine, vol. 350, no. 11, pp. 1104-1110, 2004.

[64] K. A. Petersen, S. Birk, L. H. Lassen et al., "The CGRPantagonist, BIBN4096BS does not affect cerebral or systemic haemodynamics in healthy volunteers," Cephalalgia, vol. 25, no. 2, pp. 139-147, 2005.

[65] T. W. Ho, A. P. Ho, B. R. Chaitman et al., "Randomized, controlled study of telcagepant in patients with migraine and coronary artery disease," Headache, vol. 52, no. 2, pp. 224-235, 2012.

[66] A. MaassenVanDenBrink, J. Meijer, C. M. Villalón, and M. D. Ferrari, "Wiping Out cgrp: potential Cardiovascular Risks," Trends in Pharmacological Sciences, vol. 37, no. 9, pp. 779-788, 2016.

[67] M. E. Bigal, D. W. Dodick, A. M. Rapoport et al., "Safety, tolerability, and efficacy of TEV-48125 for preventive treatment of high-frequency episodic migraine: a multicentre, randomised, double-blind, placebo-controlled, phase $2 \mathrm{~b}$ study," The Lancet Neurology, vol. 14, no. 11, pp. 1081-1090, 2015.

[68] M. E. Bigal, L. Edvinsson, A. M. Rapoport et al., "Safety, tolerability, and efficacy of TEV-48125 for preventive treatment of chronic migraine: a multicentre, randomised, double-blind, placebo-controlled, phase 2b study," The Lancet Neurology, vol. 14, no. 11, pp. 1091-1100, 2015.

[69] J. Mair, P. Lechleitner, T. Längle, C. Wiedermann, F. Dienstl, and A. Saria, "Plasma CGRP in acute myocardial infarction," The Lancet, vol. 335, no. 8682, p. 168, 1990.

[70] Y. Li, R. R. Fiscus, J. Wu, L. Yang, and X. Wang, "The antiproliferative effects of calcitonin gene-related peptide in different passages of cultured vascular smooth muscle cells," Neuropeptides, vol. 31, no. 5, pp. 503-509, 1997.

[71] W. Wang, W. Sun, and X. Wang, "Intramuscular gene transfer of CGRP inhibits neointimal hyperplasia after balloon injury in the rat abdominal aorta," American Journal of PhysiologyHeart and Circulatory Physiology, vol. 287, no. 4, pp. H1582H1589, 2004.

[72] A. Hægerstrand, C.-J. Dalsgaard, B. Jonzon, O. Larsson, and J. Nilsson, "Calcitonin gene-related peptide stimulates proliferation of human endothelial cells," Proceedings of the National Academy of Sciences of the United States of America, vol. 87, no. 9, pp. 3299-3303, 1990.

[73] I. Odar-Cederlof, E. Theodorsson, C.-G. Eriksson, and C. M. Kjellstrand, "Plasma concentrations of calcitonin generelated peptide increase during haemodialysis: relation to blood pressure," The Journal of Internal Medicine, vol. 226, no. 3, pp. $177-182,1989$.

[74] T. Taguchi, H. Kawasaki, T. Imamura, and K. Takasaki, "Endogenous calcitonin gene-related peptide mediates nonadrenergic noncholinergic depressor response to spinal cord stimulation in the pithed rat," Circulation Research, vol. 71, no. 2, pp. 357-364, 1992.

[75] S. D. Brain, T. J. Williams, J. R. Tippins, H. R. Morris, and I. MacIntyre, "Calcitonin gene-related peptide is a potent vasodilator," Nature, vol. 313, no. 5997, pp. 54-56, 1985.

[76] G. C. Grace, G. J. Dusting, B. E. Kemp, and T. J. Martin, "Endothelium and the vasodilator action of rat calcitonin generelated peptide (CGRP)," British Journal of Pharmacology, vol. 91, no. 4, pp. 729-733, 1987.

[77] D. W. Gray and I. Marshall, "Human $\alpha$-calcitonin gene-related peptide stimulates adenylate cyclase and guanylate cyclase and relaxes rat thoracic aorta by releasing nitric oxide," British Journal of Pharmacology, vol. 107, no. 3, pp. 691-696, 1992.

[78] D. W. Gray and I. Marshall, "Nitric oxide synthesis inhibitors attenuate calcitonin gene-related peptide endotheliumdependent vasorelaxation in rat aorta," European Journal of Pharmacology, vol. 212, no. 1, pp. 37-42, 1992.

[79] B. Greenberg, K. Rhoden, and P. Barnes, "Calcitonin generelated peptide (CGRP) is a potent non-endotheliumdependent inhibitor of coronary vasomotor tone," British Journal of Pharmacology, vol. 92, no. 4, pp. 789-794, 1987.

[80] N. Aiyar, J. Disa, J. M. Stadel, and P. G. Lysko, "Calcitonin gene-related peptide receptor independently stimulates 3,5'cyclic adenosine monophosphate and $\mathrm{Ca}^{2+}$ signaling pathways," Molecular and Cellular Biochemistry, vol. 197, no. 1-2, pp. 179$185,1999$.

[81] R. Yoshimoto, M. Mitsui-Saito, H. Ozaki, and H. Karaki, "Effects of adrenomedullin and calcitonin gene-related peptide 
on contractions of the rat aorta and porcine coronary artery," British Journal of Pharmacology, vol. 123, no. 8, pp. 1645-1654, 1998.

[82] M. T. Nelson, Y. Huang, J. E. Brayden, J. Hescheler, and N. B. Standen, "Arterial dilations in response to calcitonin generelated peptide involve activation of $\mathrm{K}^{+}$channels," Nature, vol. 344, no. 6268, pp. 770-773, 1990.

[83] F. M. Wisskirchen, R. P. Burt, and I. Marshall, "Pharmacological characterization of CGRP receptors mediating relaxation of the rat pulmonary artery and inhibition of twitch responses of the rat vas deferens," British Journal of Pharmacology, vol. 123, no. 8, pp. 1673-1683, 1998.

[84] E. Butt, M. Bernhardt, A. Smolenski et al., "Endothelial nitricoxide synthase (type III) is activated and becomes calcium independent upon phosphorylation by cyclic nucleotide-dependent protein kinases," The Journal of Biological Chemistry, vol. 275, no. 7, pp. 5179-5187, 2000.

[85] G. Mazzocchi, L. K. Malendowicz, V. Meneghelli, and G. G. Nussdorfer, "Calcitonin gene-related peptide depresses the growth and secretory activity of rat adrenal zona glomerulosa," Neuropeptides, vol. 21, no. 3, pp. 157-161, 1992.

[86] C. Tortorella, C. Macchi, M. Forneris, and G. G. Nussdorfer, "Calcitonin gene-related peptide (CGRP), acting via CGRP type 1 receptors, inhibits potassium-stimulated aldosterone secretion and enhances basal catecholamine secretion from rat adrenal gland," International Journal of Molecular Medicine, vol. 8, no. 3, pp. 261-264, 2001.

[87] D. H. Wang, J. Li, and J. Qiu, "Salt-sensitive hypertension induced by sensory denervation: introduction of a new model," Hypertension, vol. 32, no. 4, pp. 649-653, 1998.

[88] Y. Huang and D. H. Wang, "Role of renin-angiotensinaldosterone system in salt-sensitive hypertension induced by sensory denervation," American Journal of Physiology-Heart and Circulatory Physiology, vol. 281, no. 5, pp. H2143-H2149, 2001.

[89] Y. Huang and D. H. Wang, "Role of $\mathrm{AT}_{1}$ and $\mathrm{AT}_{2}$ receptor subtypes in salt-sensitive hypertension induced by sensory nerve degeneration," Journal of Hypertension, vol. 19, no. 10, pp. 1841-1846, 2001.

[90] D. H. Wang and J. Li, "Antihypertensive mechanisms underlying a novel salt-sensitive hypertensive model induced by sensory denervation," Hypertension, vol. 33, no. 1, pp. 499-503, 1999.

[91] J. Li, H. Zhao, S. C. Supowit, D. J. DiPette, and D. H. Wang, "Activation of the renin-angiotensin system in alpha-calcitonin gene-related peptide/calcitonin gene knockout mice," Journal of Hypertension, vol. 22, no. 7, pp. 1345-1349, 2004.

[92] H. Kawasaki, M. Takenaga, H. Araki, K. Futagami, and Y. Gomita, "Angiotensin inhibits neurotransmission of calcitonin gene-related peptide-containing vasodilator nerves in mesenteric artery of spontaneously hypertensive rats," Journal of Pharmacology and Experimental Therapeutics, vol. 284, no. 2, pp. 508-515, 1998.

[93] N. Hobara, N. Gessei-Tsutsumi, M. Goda et al., "Longterm inhibition of angiotensin prevents reduction of periarterial innervation of calcitonin gene-related peptide (CGRP)containing nerves in spontaneously hypertensive rats," Hypertension Research, vol. 28, no. 5, pp. 465-474, 2005.

[94] H. Kawasaki, C. Nuki, A. Saito, and K. Takasaki, "Adrenergic modulation of calcitonin gene-related peptide (CGRP)containing nerve-mediated vasodilation in the rat mesenteric resistance vessel," Brain Research, vol. 506, no. 2, pp. 287-290, 1990.
[95] M. Takenaga and H. Kawasaki, "Endogenous calcitonin generelated peptide suppresses vasoconstriction mediated by adrenergic nerves in rat mesenteric resistance blood vessels," European Journal of Pharmacology, vol. 367, no. 2-3, pp. 239-245, 1999.

[96] H. Kurihara, T. Shindo, Y. Oh-Hashi, Y. Kurihara, and T. Kuwaki, "Targeted disruption of adrenomedullin and $\alpha$ CGRP genes reveals their distinct biological roles," Hypertension Research, vol. 26, pp. S105-S108, 2003.

[97] C. Nuki, H. Kawasaki, K. Takasaki, and A. Wada, "Pharmacological characterization of presynaptic calcitonin gene-related peptide (CGRP) receptors on CGRP-containing vasodilator nerves in rat mesenteric resistance vessels," Journal of Pharmacology and Experimental Therapeutics, vol. 268, no. 1, pp. 59-64, 1994.

[98] A. P. de Jong and M. Verhage, "Presynaptic signal transduction pathways that modulate synaptic transmission," Current Opinion in Neurobiology, vol. 19, no. 3, pp. 245-253, 2009.

[99] S. C. Supowit, H. Zhao, D. M. Hallman, and D. J. DiPette, "Calcitonin gene-related peptide is a depressor in subtotal nephrectomy hypertension," Hypertension, vol. 31, no. 1, pp. 391396, 1998.

[100] S. P. H. Alexander, A. P. Davenport, E. Kelly et al., "The Concise Guide to PHARMACOLOGY 2015/16: G proteincoupled receptors," British Journal of Pharmacology, vol. 172, no. 24, pp. 5744-5869, 2015.

[101] C. M. Villalón, J. A. Albarrán-Juárez, J. Lozano-Cuenca, H. H. Pertz, T. Görnemann, and D. Centurión, "Pharmacological profile of the clonidine-induced inhibition of vasodepressor sensory outflow in pithed rats: correlation with $\alpha_{2 A / 2 C^{-}}$ adrenoceptors," British Journal of Pharmacology, vol. 154, no. 1, pp. 51-59, 2008.

[102] C. Nuki, H. Kawasaki, and K. Takasaki, "Effect of neuropeptide $\mathrm{Y}$ on vasodilation mediated by calcitonin gene-related peptide (CGRP)-containing nerves in the mesenteric resistance vessel of the rat," The Japanese Journal of Pharmacology, vol. 53, no. 1, pp. 125-128, 1990.

[103] H. Kawasaki, C. Nuki, A. Saito, and K. Takasaki, "NPY modulates neurotransmission of CGRP-containing vasodilator nerves in rat mesenteric arteries," American Journal of Physiology-Heart and Circulatory Physiology, vol. 261, no. 3, pp. H683-H690, 1991.

[104] H. Kawasaki and K. Takasaki, "Vasoconstrictor response induced by 5 -hydroxytryptamine released from vascular adrenergic nerves by periarterial nerve stimulation," The Journal of Pharmacology and Experimental Therapeutics, vol. 229, no. 3, pp. 816-822, 1984.

[105] H. Fujii, S. Takatori, Y. Zamami et al., "Adrenergic stimulationreleased 5-HT stored in adrenergic nerves inhibits CGRPergic nerve-mediated vasodilatation in rat mesenteric resistance arteries," British Journal of Pharmacology, vol. 166, no. 7, pp. 2084-2094, 2012.

[106] D. J. Williamson, R. J. Hargreaves, R. G. Hill, and S. L. Shepheard, "Sumatriptan inhibits neurogenic vasodilation of dural blood vessels in the anaesthetized rat-Intravital microscope studies," Cephalalgia, vol. 17, no. 4, pp. 525-531, 1997.

[107] V. Limmroth, Z. Katsarava, B. Liedert et al., "An in vivo rat model to study calcitonin gene related peptide release following activation of the trigeminal vascular system," Pain, vol. 92, no. 1-2, pp. 101-106, 2001.

[108] S. Gupta, S. Akerman, A. M. J. M. van den Maagdenberg, P. R. Saxena, P. J. Goadsby, and A. M. Van Den Brink, "Intravital 
microscopy on a closed cranial window in mice: a model to study trigeminovascular mechanisms involved in migraine," Cephalalgia, vol. 26, no. 11, pp. 1294-1303, 2006.

[109] M. G. Buzzi, W. B. Carter, T. Shimizu, H. Heath III, and M. A. Moskowitz, "Dihydroergotamine and sumatriptan attenuate levels of CGRP in plasma in rat superior sagittal sinus during electrical stimulation of the trigeminal ganglion," Neuropharmacology, vol. 30, no. 11, pp. 1193-1200, 1991.

[110] J. Lozano-Cuenca, A. González-Hernández, E. Muñoz-Islas et al., "Effect of some acute and prophylactic antimigraine drugs on the vasodepressor sensory CGRPergic outflow in pithed rats," Life Sciences, vol. 84, no. 5-6, pp. 125-131, 2009.

[111] A. González-Hernández, E. Muñoz-Islas, J. Lozano-Cuenca et al., "Activation of 5- $\mathrm{HT}_{1 B}$ receptors inhibits the vasodepressor sensory CGRPergic outflow in pithed rats," European Journal of Pharmacology, vol. 637, no. 1-3, pp. 131-137, 2010.

[112] A. González-Hernández, G. Manrique-Maldonado, J. LozanoCuenca et al., "The 5- $\mathrm{HT}_{1}$ receptors inhibiting the rat vasodepressor sensory CGRPergic outflow: further involvement of 5$\mathrm{HT}_{1 F}$, but not $5-\mathrm{HT}_{1 A}$ or $5-\mathrm{HT}_{1 D}$, subtypes," European Journal of Pharmacology, vol. 659, no. 2-3, pp. 233-243, 2011.

[113] C. Cuesta, J. Á. García-Pedraza, M. García, C. M. Villalón, and A. Morán, "Role of $5-\mathrm{HT}_{7}$ receptors in the inhibition of the vasodepressor sensory CGRPergic outflow in pithed rats," Vascular Pharmacology, vol. 63, no. 1, pp. 4-12, 2014.

[114] G. Manrique-Maldonado, A. González-Hernández, A. H. Altamirano-Espinoza, B. A. Marichal-Cancino, I. Ruiz-Salinas, and C. M. Villalón, "The role of pre-junctional $\mathrm{D}_{2}$-like receptors mediating quinpirole-induced inhibition of the vasodepressor sensory CGRPergic out-flow in pithed rats," Basic and Clinical Pharmacology and Toxicology, vol. 114, no. 2, pp. 174-180, 2014.

[115] Y. Haruki, S. Takatori, S. Hattori, Y. Zamamiet et al., "Adrenergic stimulation-released histamine taken-up in adrenergic nerves induces endothelium-dependent vasodilation in rat mesenteric resistance arteries," The Japanese Pharmacological Sciences, vol. 118, pp. 537-542, 2012.

[116] G. Manrique-Maldonado, A. H. Altamirano-Espinoza, B. A. Marichal-Cancino, E. Rivera-Mancilla, V. Avilés-Rosas, and C. M. Villalón, "Pharmacological evidence that histamine $\mathrm{H}_{3}$ receptors inhibit the vasodepressor responses by selective stimulation of the rat perivascular sensory CGRPergic outflow," European Journal of Pharmacology, vol. 754, pp. 25-31, 2015.

[117] P. Sun, S. Takatori, X. Jin et al., "Histamine $\mathrm{H}_{3}$ receptormediated modulation of perivascular nerve transmission in rat mesenteric arteries," European Journal of Pharmacology, vol. 655, no. 1-3, pp. 67-73, 2011.

[118] T. Sugiyama, Y. Hatanaka, Y. Iwatani, X. Jin, and H. Kawasaki, "Lafutidine facilitates calcitonin gene-related peptide (CGRP) nerve-mediated vasodilation via vanilloid-1 receptors in rat mesenteric resistance arteries," Journal of Pharmacological Sciences, vol. 106, no. 3, pp. 505-511, 2008.

[119] H. Kawasaki, S. Eguchi, S. Miyashita et al., "Proton acts as a neurotransmitter for nicotine-induced adrenergic and calcitonin gene-related peptide-containing nerve-mediated vasodilation in the rat mesenteric artery," The Journal of Pharmacology and Experimental Therapeutics, vol. 330, no. 3, pp. 745-755, 2009.

[120] S. Takatori, K. Hirai, S. Ozaki et al., "Protons modulate perivascular axo-axonal neurotransmission in the rat mesenteric artery," British Journal of Pharmacology, vol. 171, no. 24, pp. 5743-5756, 2014.
[121] H. Kawasaki, S. Takatori, Y. Zamami et al., "Paracrine control of mesenteric perivascular axo-axonal interaction," Acta Physiologica, vol. 203, no. 1, pp. 3-11, 2011.

[122] A. M. Aloisi, "Gonadal hormones and sex differences in pain reactivity," Clinical Journal of Pain, vol. 19, no. 3, pp. 168-174, 2003.

[123] S. Gupta, S. Mehrotra, C. Villalón et al., "Effects of female sex hormones on responses to CGRP, acetylcholine, and 5-HT in rat isolated arteries," Headache, vol. 47, no. 4, pp. 564-575, 2007.

[124] S. Gupta, C. M. Villalón, S. Mehrotra et al., "Female sex hormones and rat dural vasodilatation to CGRP, periarterial electrical stimulation and capsaicin," Headache, vol. 47, no. 2, pp. 225-235, 2007.

[125] N. R. Poulter, D. Prabhakaran, and M. Caulfield, "Hypertension," The Lancet, vol. 386, no. 9995, pp. 801-812, 2015.

[126] P.-Y. Deng and Y.-J. Li, "Calcitonin gene-related peptide and hypertension," Peptides, vol. 26, no. 9, pp. 1676-1685, 2005.

[127] D. T. Lackland and M. A. Weber, "Global burden of cardiovascular disease and stroke: hypertension at the core," The Canadian Journal of Cardiology, vol. 31, no. 5, pp. 569-571, 2015.

[128] N. Hashikawa-Hobara, N. Hashikawa, Y. Zamami, S. Takatori, and $\mathrm{H}$. Kawasaki, "The mechanism of calcitonin gene-related peptide-containing nerve innervation," The Journal of Pharmacological Sciences, vol. 119, no. 2, pp. 117-121, 2012.

[129] A. Dutta and S. B. Deshpande, "Mechanisms underlying the hypertensive response induced by capsaicin," International Journal of Cardiology, vol. 145, no. 2, pp. 358-359, 2010.

[130] R. E. Watson, S. C. Supowit, H. Zhao, K. A. Katki, and D. J. DiPette, "Role of sensory nervous system vasoactive peptides in hypertension," Brazilian Journal of Medical and Biological Research, vol. 35, no. 9, pp. 1033-1045, 2002.

[131] T. H. Mai, J. Wu, A. Diedrich, E. M. Garland, and D. Robertson, "Calcitonin gene-related peptide (CGRP) in autonomic cardiovascular regulation and vascular structure," Journal of the American Society of Hypertension, vol. 8, no. 5, pp. 286-296, 2014.

[132] F. A. Russell, R. King, S.-J. Smillie, X. Kodji, and S. D. Brain, "Calcitonin gene-related peptide: physiology and pathophysiology," Physiological Reviews, vol. 94, no. 4, pp. 1099-1142, 2014.

[133] Z. Wang, B. C. Martorell, T. Wälchli et al., "Calcitonin generelated peptide (CGRP) Receptors are important to maintain cerebrovascular reactivity in chronic hypertension," PLOS ONE, vol. 10, no. 4, Article ID e0123697, 2015.

[134] F. Portaluppi, G. Trasformi, A. Margutti et al., "Circadian rhythm of calcitonin gene-related peptide in uncomplicated essential hypertension," Journal of Hypertension, vol. 10, no. 10, pp. 1227-1234, 1992.

[135] -A. S. Tjen-Looi, R. Ekman, H. Lippton, J. Cary, and I. Keith, "CGRP and somatostatin modulate chronic hypoxic pulmonary hypertension," American Journal of Physiology, vol. 263, no. 3, pp. H681-H690, 1992.

[136] X.-L. Luo, T.-L. Yang, X.-P. Chen, and Y.-J. Li, "Association of CALCA genetic polymorphism with essential hypertension," Chinese Medical Journal, vol. 121, no. 15, pp. 1407-1410, 2008.

[137] Y. Oh-hashi, T. Shindo, Y. Kurihara et al., "Elevated sympathetic nervous activity in mice deficient in $\alpha$ CGRP," Circulation Research, vol. 89, no. 11, pp. 983-990, 2001.

[138] S.-J. Smillie, R. King, X. Kodji et al., "An ongoing role of $\alpha$ calcitonin gene-related peptide as part of a protective network against hypertension, vascular hypertrophy, and oxidative stress," Hypertension, vol. 63, no. 5, pp. 1056-1062, 2014. 
[139] S.-J. Smillie and S. D. Brain, "Calcitonin gene-related peptide (CGRP) and its role in hypertension," Neuropeptides, vol. 45, no. 2, pp. 93-104, 2011.

[140] A. Masuda, K. Shimamoto, Y. Mori, M. Nakagawa, N. Ura, and O. Limura, "Plasma calcitonin gene-related peptide levels in patients with various hypertensive diseases," Journal of Hypertension, vol. 10, no. 12, pp. 1499-1504, 1992.

[141] S. Schifter, L. R. Krusell, and J. Sehested, "Normal serum levels of calcitonin gene-related peptide (CGRP) in mild to moderate essential hypertension," American Journal of Hypertension, vol. 4, no. 7, pp. 565-569, 1991.

[142] S. C. Supowit, C. V. Ramana, K. N. Westlund, and D. J. DiPette, "Calcitonin gene-related peptide gene expression in the spontaneously hypertensive rat," Hypertension, vol. 21, no. 6, pp. 1010-1014, 1993.

[143] P.-Y. Deng, F. Ye, W.-J. Cai, H.-W. Deng, and Y.-J. Li, "Role of calcitonin gene-related peptide in the phenol-induced neurogenic hypertension in rats," Regulatory Peptides, vol. 119, no. 3, pp. 155-161, 2004.

[144] P. R. R. Gangula, S. C. Supowit, S. J. Wimalawansa et al., "Calcitonin gene-related peptide is a depressor in NG-nitro-Larginine methyl ester-induced hypertension during pregnancy," Hypertension, vol. 29, no. 1, pp. 248-253, 1997.

[145] K. A. Katki, S. C. Supowit, and D. J. DiPette, "Role of calcitonin gene-related peptide and substance P in Dahl-salt hypertension," Hypertension, vol. 38, no. 3, pp. 679-682, 2001.

[146] S. C. Supowit, H. Zhao, D. M. Hallman, and D. J. DiPette, "Calcitonin gene-related peptide is a depressor of deoxycorticosterone-salt hypertension in the rat," Hypertension, vol. 29, no. 4, pp. 945-950, 1997.

[147] H. Kawasaki, "Effects of chronic administration of antihypertensive drugs on vasodilation mediated by calcitonin generelated peptide-containing vasodilator nerves in spontaneously hypertensive rats," Clinical \& Experimental Pharmacology and Physiology, vol. 19, no. 8, pp. 569-573, 1992.

[148] H. Kawasaki, Y. Nuki, N. Yamaga, Y. Kurosaki, and T. Taguchi, "Decreased depressor response mediated by calcitonin generelated peptide (CGRP)-containing vasodilator nerves to spinal cord stimulation and levels of CGRP mRNA of the dorsal root ganglia in spontaneously hypertensive rats," Hypertension Research, vol. 23, no. 6, pp. 693-699, 2000.

[149] S. Takatori, Y. Zamami, M. Mio, Y. Kurosaki, and H. Kawasaki, "Chronic hyperinsulinemia enhances adrenergic vasoconstriction and decreases calcitonin gene-related peptide-containing nerve-mediated vasodilation in pithed rats," Hypertension Research, vol. 29, no. 5, pp. 361-368, 2006.

[150] Y. Zamami, S. Takatori, N. Hobara et al., "Hyperinsulinemia induces hypertension associated with neurogenic vascular dysfunction resulting from abnormal perivascular innervations in rat mesenteric resistance arteries," Hypertension Research, vol. 34, no. 11, pp. 1190-1196, 2011.

[151] S. Takatori, H. Fujiwara, Y. Zamami, N. Hashikawa-Hobara, and H. Kawasaki, "Decreased perivascular CGRP-containing nerves in Otsuka Long-Evans Tokushima Fatty rats with insulin resistance and hypertension," Hypertension Research, vol. 37, no. 5, pp. 398-404, 2014.

[152] S. Takatori, Y. Zamami, N. Yabumae et al., "Pioglitazone opposes neurogenic vascular dysfunction associated with chronic hyperinsulinaemia," British Journal of Pharmacology, vol. 153, no. 7, pp. 1388-1398, 2008.
[153] Y. Zamami, S. Takatori, K. Yamawaki et al., "Acute hyperglycemia and hyperinsulinemia enhance adrenergic vasoconstriction and decrease calcitonin gene-related peptidecontaining nerve-mediated vasodilation in pithed rats," Hypertension Research, vol. 31, no. 5, pp. 1033-1044, 2008.

[154] B. W. Mol, C. T. Roberts, S. Thangaratinam, L. A. Magee, C. J. de Groot, and G. J. Hofmeyr, "Pre-eclampsia," The Lancet, vol. 387, no. 10022, pp. 999-1011, 2016.

[155] WHO Recommendations for Prevention and Treatment of PreEclampsia and Eclampsia, 2011.

[156] S. Saleem, E. M. McClure, S. S. Goudar et al., "A prospective study of maternal, fetal and neonatal deaths in low- and middleincome countries," Bulletin of the World Health Organization, vol. 92, no. 8, pp. 605-612, 2014.

[157] F. H. Epstein, "Late vascular effects of toxemia of pregnancy," The New England Journal of Medicine, vol. 271, pp. 391-395, 1964.

[158] L. Bellamy, J.-P. Casas, A. D. Hingorani, and D. J. Williams, "Pre-eclampsia and risk of cardiovascular disease and cancer in later life: systematic review and meta-analysis," British Medical Journal, vol. 335, no. 7627, pp. 974-986, 2007.

[159] N. Al-Jameil, F. Aziz Khan, M. Fareed Khan, and H. Tabassum, "A brief overview of preeclampsia," Journal of Clinical Medicine Research, vol. 6, no. 1, pp. 1-7, 2014.

[160] E. A. P. Steegers, P. Von Dadelszen, J. J. Duvekot, and R. Pijnenborg, "Pre-eclampsia," The Lancet, vol. 376, no. 9741, pp. 631-644, 2010.

[161] H. S. Liu, T. Y. Chu, M. H. Yu, Y. K. Chang, C. S. Ko, and C. F. Chao, "Thromboxane and prostacyclin in maternal and fetal circulation in pre-eclampsia," International Journal of Gynecology and Obstetrics, vol. 63, no. 1, pp. 1-6, 1998.

[162] A. C. Bolte, H. P. Van Geijn, and G. A. Dekker, "Pathophysiology of preeclampsia and the role of serotonin," European Journal of Obstetrics Gynecology and Reproductive Biology, vol. 95, no. 1, pp. 12-21, 2001.

[163] J. A. Ferreira-de-Almeida, F. Amenta, F. Cardoso, and J. J. Polonia, "Association of circulating endothelin and noradrenaline with increased calcium-channel binding sites in the placental bed in pre-eclampsia," British Journal of Obstetrics and Gynaecology, vol. 105, no. 10, pp. 1104-1112, 1998.

[164] A. Halhali, S. J. Wimalawansa, V. Berentsen, E. Avila, C. S. Thota, and F. Larrea, "Calcitonin gene- and parathyroid hormone-related peptides in preeclampsia: effects of magnesium sulfate," Obstetrics and Gynecology, vol. 97, no. 6, pp. 893897, 2001.

[165] I. Knerr, C. Dachert, E. Beinder et al., "Adrenomedullin, calcitonin gene-related peptide and their receptors: evidence for a decreased placental mRNA content in preeclampsia and HELLP syndrome," European Journal of Obstetrics Gynecology \& Reproductive Biology, vol. 101, no. 1, pp. 47-53, 2002.

[166] M.E. A. Spaanderman, T. H. A. Ekhart, P. W. De Leeuw, and L. L. H. Peeters, "Angiotensin II sensitivity in nonpregnant formerly preeclamptic women and healthy parous controls," Journal of the Society for Gynecologic Investigation, vol. 11, no. 6, pp. 416422, 2004.

[167] Y.-L. Dong, S. Vegiraju, M. Chauhan et al., "Involvement of calcitonin gene-related peptide in control of human fetoplacental vascular tone," American Journal of Physiology-Heart and Circulatory Physiology, vol. 286, no. 1, pp. H230-H239, 2004.

[168] Y.-L. Dong, K. E. Green, S. Vegiragu et al., "Evidence for decreased calcitonin gene-related peptide (CGRP) receptors and compromised responsiveness to CGRP of fetoplacental 
vessels in preeclamptic pregnancies," The Journal of Clinical Endocrinology \& Metabolism, vol. 90, no. 4, pp. 2336-2343, 2005.

[169] C. Yallampalli, Y.-L. Dong, and S. J. Wimalawansa, "Calcitonin gene-related peptide reverses the hypertension and significantly decreases the fetal mortality in pre-eclampsia rats induced by NG-nitro-L-arginine methyl ester," Human Reproduction, vol. 11, no. 4, pp. 895-899, 1996.

[170] S. K. Parida, D. B. Schneider, T. D. Stoss, T. H. Pauly, and J. P. McGillis, "Elevated circulating calcitonin gene-related peptide in umbilical cord and infant blood associated with maternal and neonatal sepsis and shock," Pediatric Research, vol. 43, no. 2, pp. 276-282, 1998.

[171] C. Yallampalli and S. J. Wimalawansa, "Calcitonin gene-related peptide (CGRP) is a mediator of vascular adaptations during hypertension in pregnancy," Trends in Endocrinology \& Metabolism, vol. 9, no. 3, pp. 113-117, 1998.

[172] X. Fei, Z. Hongxiang, C. Qi, and C. Daozhen, "Maternal plasma levels of endothelial dysfunction mediators including AM, CGRP, sICAM-1 and tHcy in pre-eclampsia," Advances in Clinical and Experimental Medicine, vol. 21, no. 5, pp. 573-579, 2012.

[173] A. C. Ariza, N. Bobadilla, C. Fernández, R. M. Muñoz-Fuentes, F. Larrea, and A. Halhali, "Effects of magnesium sulfate on lipid peroxidation and blood pressure regulators in preeclampsia," Clinical Biochemistry, vol. 38, no. 2, pp. 128-133, 2005.

[174] A. C. Ariza, N. Bobadilla, L. Díaz, E. Avila, F. Larrea, and A. Halhali, "Placental gene expression of calcitonin gene-related peptide and nitric oxide synthases in preeclampsia: effects of magnesium sulfate," Magnesium Research, vol. 22, no. 1, pp. 4449, 2009.

[175] S. Yadav, Y. S. Yadav, M. M. Goel, U. Singh, S. M. Natu, and M. P. S. Negi, "Calcitonin gene- and parathyroid hormonerelated peptides in normotensive and preeclamptic pregnancies: a nested case-control study," Archives of Gynecology and Obstetrics, vol. 290, no. 5, pp. 897-903, 2014.

[176] S. Akerman, P. R. Holland, and P. J. Goadsby, "Diencephalic and brainstem mechanisms in migraine," Nature Reviews Neuroscience, vol. 12, no. 10, pp. 570-584, 2011.

[177] E. Shevel, "The extracranial vascular theory of migraine-a great story confirmed by the facts," Headache, vol. 51, no. 3, pp. 409-417, 2011.

[178] M. S. Asghar, L. Becerra, H. B. Larsson, D. Borsook, M. Ashina, and J. Porter, "Calcitonin gene-related peptide modulates heat nociception in the human brain-an fMRI study in healthy volunteers," PLoS ONE, vol. 11, no. 3, Article ID e0150334, 2016.

[179] H. C. Diener and D. W. Dodick, "Headache research in 2015: progress in migraine treatment," The Lancet Neurology, vol. 15, no. 1, pp. 4-5, 2016.

[180] L. Edvinsson, "CGRP receptor antagonists and antibodies against CGRP and its receptor in migraine treatment," British Journal of Clinical Pharmacology, vol. 80, no. 2, pp. 193-199, 2015.

[181] C. F. Marfurt, "The somatotopic organization of the cat trigeminal ganglion as determined by the horseradish peroxidase technique," Anatomical Record, vol. 201, no. 1, pp. 105-118, 1981.

[182] A. May, H. Kaube, C. Büchel et al., "Experimental cranial pain elicited by capsaicin: a PET study," Pain, vol. 74, no. 1, pp. 61-66, 1998.

[183] S. Eftekhari, K. Warfvinge, F. W. Blixt, and L. Edvinsson, "Differentiation of nerve fibers storing CGRP and CGRP receptors in the peripheral trigeminovascular system," The Journal of Pain, vol. 14, no. 11, pp. 1289-1303, 2013.

[184] S. J. Peroutka, "Neurogenic inflammation and migrane: implications for therapeutics," Molecular Interventions, vol. 5, no. 5, pp. 304-311, 2005.

[185] J. Olesen, H.-C. Diener, I. W. Husstedt et al., "Calcitonin generelated peptide receptor antagonist BIBN 4096 BS for the acute treatment of migraine," The New England Journal of Medicine, vol. 350, no. 11, pp. 1104-1110, 2004.

[186] E. Muñoz-Islas, A. González-Hernández, J. Lozano-Cuenca et al., "Inhibitory effect of chronic oral treatment with fluoxetine on capsaicin-induced external carotid vasodilatation in anaesthetised dogs," Cephalalgia, vol. 35, no. 12, pp. 1041-1053, 2015.

[187] S. Vilotti, N. Vana, A. M. Van den Maagdenberg, and A. Nistri, "Expression and function of calcitonin gene-related peptide (CGRP) receptors in trigeminal ganglia of R192Q Cacnala knock-in mice," Neuroscience Letters, vol. 620, pp. 104-110, 2016.

[188] I. L. Kröger and A. May, "Triptan-induced disruption of trigemino-cortical connectivity," Neurology, vol. 84, no. 21, pp. 2124-2131, 2015.

[189] L. R. Jiménez-Mena, S. Gupta, E. Muñoz-Islas et al., "Clonidine inhibits the canine external carotid vasodilatation to capsaicin by $\alpha_{2 \mathrm{~A} / 2 \mathrm{C}}$-adrenoceptors," European Journal of Pharmacology, vol. 543, no. 1-3, pp. 68-76, 2006.

[190] E. Muñoz-Islas, J. Lozano-Cuenca, A. González-Hernández et al., "Spinal sumatriptan inhibits capsaicin-induced canine external carotid vasodilatation via $5-\mathrm{HT}_{1 B}$ rather than $5-\mathrm{HT}_{1 D}$ receptors," European Journal of Pharmacology, vol. 615, no. 1-3, pp. 133-138, 2009.

[191] C. M. Villalón, J. Galicia-Carreón, A. González-Hernández, B. A. Marichal-Cancino, G. Manrique-Maldonado, and D. Centurión, "Pharmacological evidence that spinal $\alpha 2 \mathrm{C}$-and, to a lesser extent, $\alpha 2 \mathrm{~A}$-adrenoceptors inhibit capsaicin-induced vasodilatation in the canine external carotid circulation," European Journal of Pharmacology, vol. 683, no. 1-3, pp. 204-210, 2012.

[192] S. Vermeersch, R. J. Benschop, A. Van Hecken et al., “Translational pharmacodynamics of calcitonin gene-related peptide monoclonal antibody LY2951742 in a capsaicin-induced dermal blood flow model," Journal of Pharmacology and Experimental Therapeutics, vol. 354, no. 3, pp. 350-357, 2015.

[193] C. M. Villalón, V. H. Avilés-Rosas, E. Rivera-Mancilla et al., "Intravenous olcegepant blocks the sensory vasodepressor CGRPergic outflow and facilitates the sympathetic vasopressor outflow in pithed rats," in Proceedings of the British Pharmacological Society Winter Meeting, 2014, http://www.pa2online.org/ abstract/abstract.jsp?abid=32357.

[194] J. T. Lu, Y.-J. Son, J. Lee et al., "Mice lacking $\alpha$-calcitonin generelated peptide exhibit normal cardiovascular regulation and neuromuscular development," Molecular and Cellular Neurosciences, vol. 14, no. 2, pp. 99-120, 1999. 


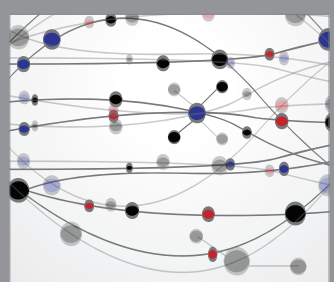

The Scientific World Journal
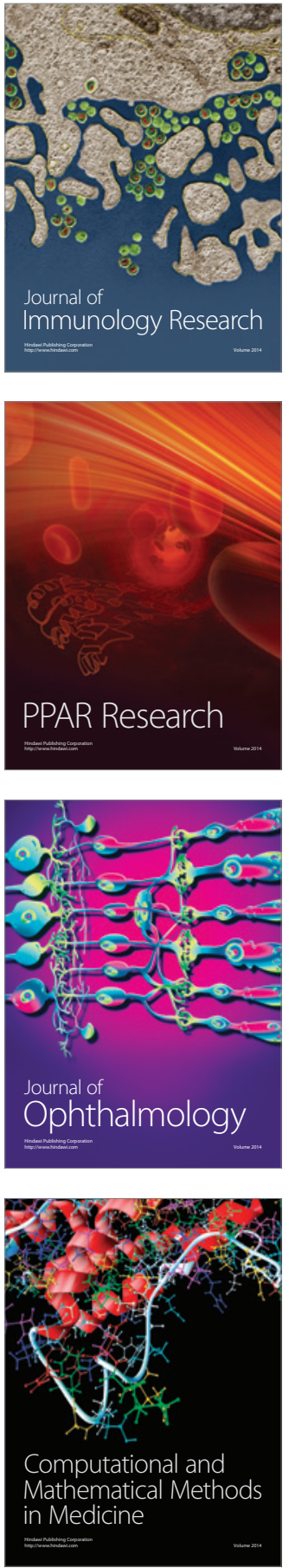

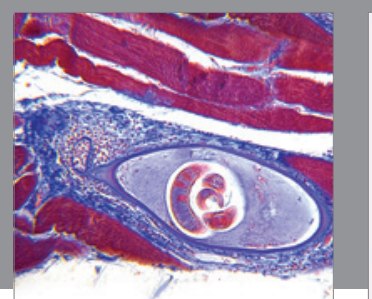

Gastroenterology Research and Practice

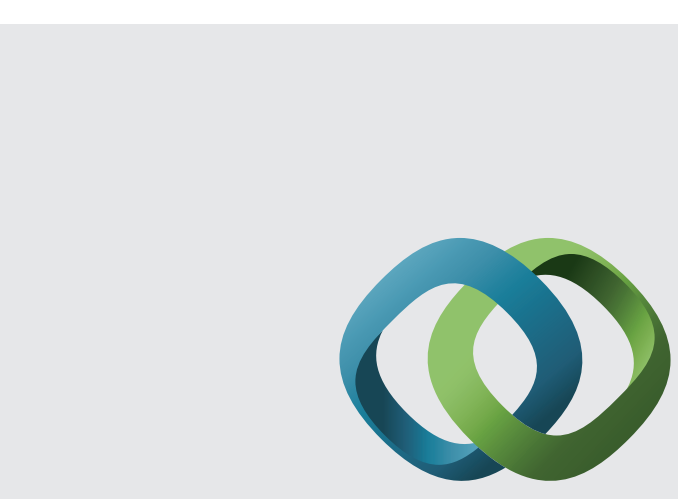

\section{Hindawi}

Submit your manuscripts at

http://www.hindawi.com
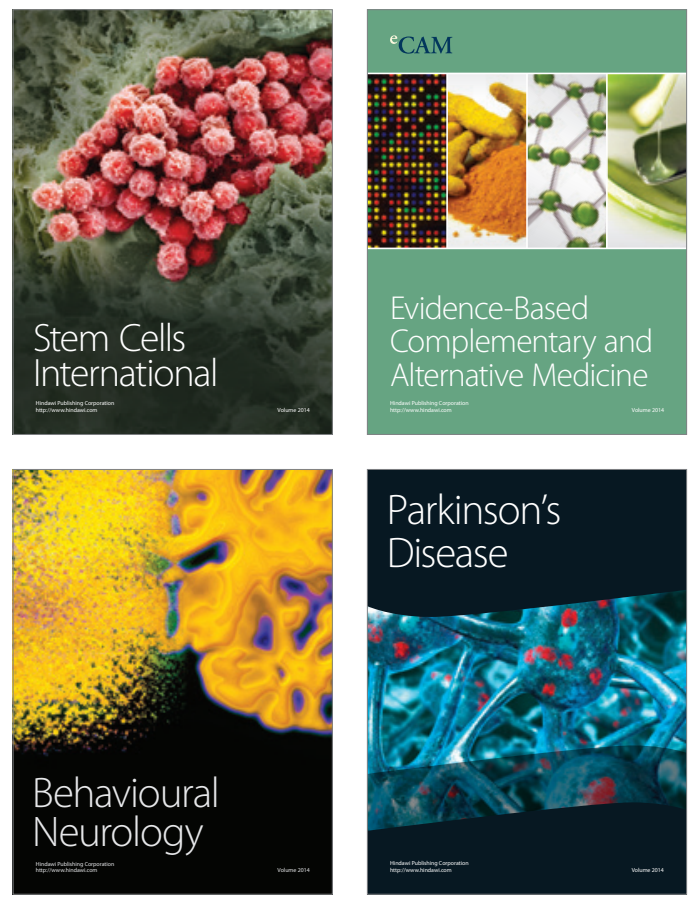
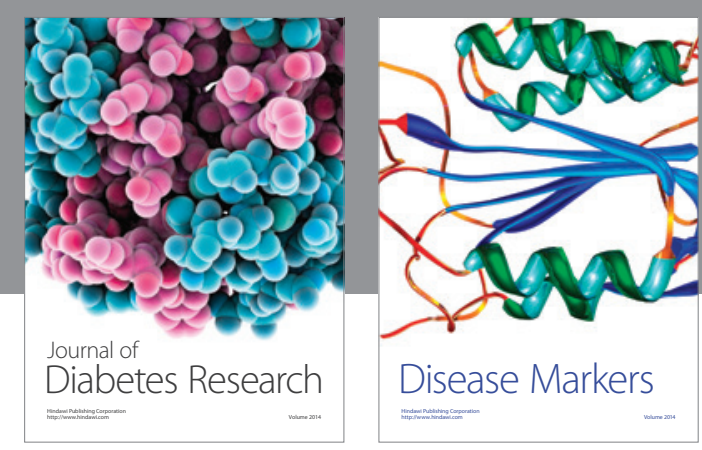

Disease Markers
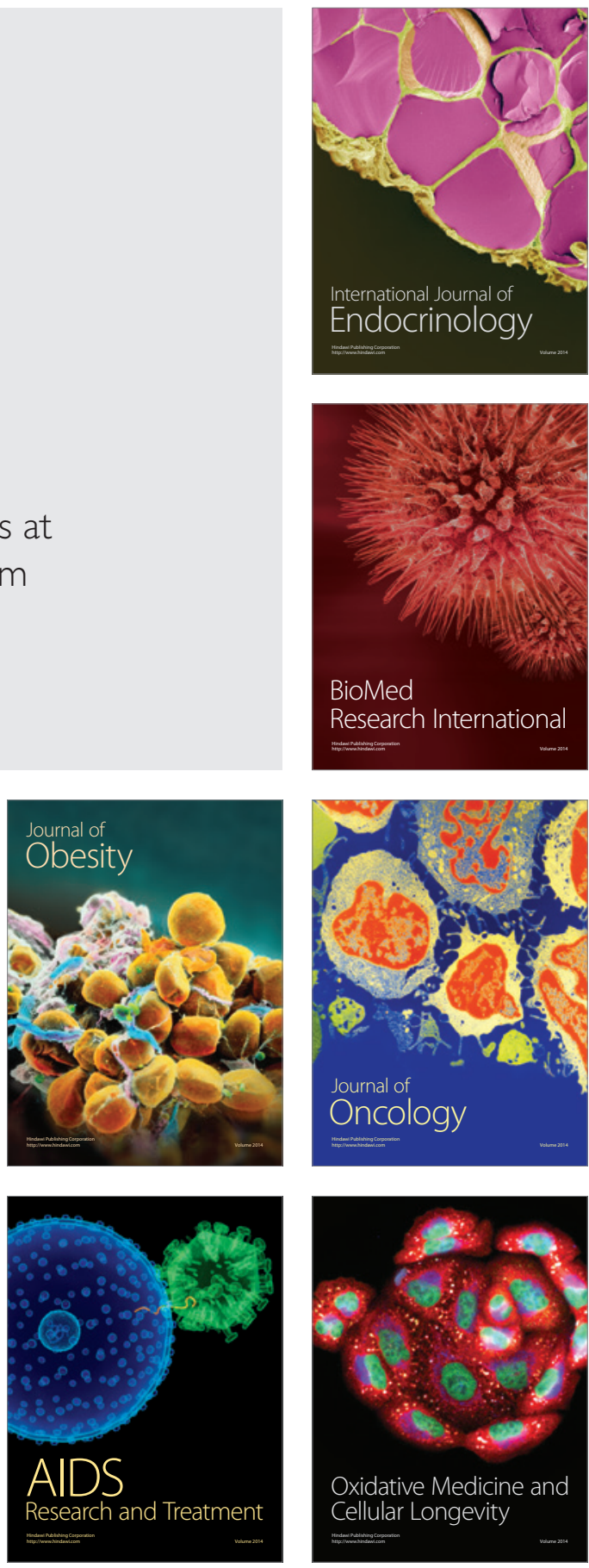